\title{
Article \\ Experimental Study of the Compressive Strengths of Basalt Fiber-Reinforced Concrete after Various High-Temperature Treatments and Cooling in Open Air and Water
}

\author{
Huaming An $\left.{ }^{1}{ }^{(}\right)$, Yushan Song ${ }^{1}{ }^{(}$, Lei Liu ${ }^{2, *}$ and Xiang Meng ${ }^{2}$ \\ 1 Faculty of Public Security and Emergency Management, Kunming University of Science and Technology, \\ Kunming 650093, China; huaming.an@kust.edu.cn (H.A.); Yushan.song@stu.kust.edu.cn (Y.S.) \\ 2 Faculty of Land Resource Engineering, Kunming University of Science and Technology, \\ Kunming 650093, China; explosive.lab@outlook.com \\ * Correspondence: kgliulei@kust.edu.cn
}

Citation: An, H.; Song, Y.; Liu, L.; Meng, X. Experimental Study of the Compressive Strengths of Basalt Fiber-Reinforced Concrete after Various High-Temperature Treatments and Cooling in Open Air and Water. Appl. Sci. 2021, 11, 8729. https://doi.org/10.3390/app11188729

Academic Editor: Chao-Wei Tang

Received: 18 August 2021

Accepted: 15 September 2021

Published: 18 September 2021

Publisher's Note: MDPI stays neutral with regard to jurisdictional claims in published maps and institutional affiliations.

Copyright: () 2021 by the authors. Licensee MDPI, Basel, Switzerland. This article is an open access article distributed under the terms and conditions of the Creative Commons Attribution (CC BY) license (https:// creativecommons.org/licenses/by/ $4.0 /)$.

\begin{abstract}
The rapid development of modern society has increased the demand for high-performance geo-materials. As an advanced cementitious composite, fiber-reinforced concrete has attracted much attention and has been widely applied to various buildings and civil infrastructure. A basalt fiber-reinforced concrete is proposed as an advanced geo-material and the mechanical and thermal properties were investigated in this study. The basalt fiber-reinforced concrete was compared with ordinary concrete to confirm its superiority by determination of the physical parameters, static compressive test, and dynamic compressive test. The static compressive test was performed using the YAW-2000C constant stress pressure experimental machine under different heating temperatures and cooling methods, while the dynamic compressive test was performed using the 75-mm splitHopkinson pressure bar under different loading rates, heating temperatures, and cooling methods. For the basic physical parameters, it was found that the mass loss and wave velocity of concrete decrease with the increase of the temperature. In the static compressive test, the static compressive strength for both the ordinary concrete and the fiber-reinforced concrete decreased with the increase of the temperature, and greater strength was observed with the air-cooled compared to the water-cooled method. It was found that the strength of basalt fiber-reinforced concrete is greater than that of ordinary concrete. In the dynamic compressive test, the strength increased with an increasing loading rate and descended with an increasing temperature, while for the same heating temperature and loading rate, water cooling produced more irregular and smaller fragments than air cooling. The dynamic compressive strength of basalt fiber-reinforced concrete was bigger than that of ordinary concrete.
\end{abstract}

Keywords: basalt fiber-reinforced concrete; high temperature; cooling methods; static compressive test; dynamic compressive test

\section{Introduction}

As one of the most promising advanced geo-materials, concrete is widely used in geoengineering owing to its wide material availability, good workability, high strength, and low cost. The earliest use of concrete can be traced back to Roman times, when concrete consisted of aggregates, such as pieces of rocks, bricks, or ceramic titles, with gypsum and quicklime as binding materials, and volcanic dust [1]. In the 20th century, concrete was extensively developed and became one of the most frequently used materials in construction [1]. However, this structure is susceptible to fire and dynamic loading. In recent years, the occurrence of fire, explosions, and earthquakes is frequently reported. Thus, it is imperative to study the thermal and dynamic behaviors of concrete with various hightemperature treatments. Nowadays, ultra-high-performance concrete (UHPC) technology is implemented to develop advanced concrete, which has superior mechanical properties 
and better durability than normal or traditional concrete. In addition, many concretes incorporate fibers to increase the tensile strength and crack resistance.

Lie, Nagy et al. carried out an experiment with regard to the thermal performance of concrete, including the thermal conductivity, density, and specific heat capacity. It was found that the changes of concretes' thermal conductivities were mainly determined by the density of concrete [2,3]. Nagy, Liang et al. regarded steel-fiber concrete as a compound material consisting of concrete matrix and fibers and simulated its thermal conductivity by using the finite-element method. They found that the addition of steel fiber significantly impacted the distributions of the heat flux and temperature. The effect of the fiber diameter on thermal conductivity is greater than that of the fiber length [3,4]. Zheng, Aslani et al. summarized the effects of high temperatures on the compressive strength, tensile strength, flexural strength, elastic modulus, peak strain, and stress-strain curves of steel-fiber concrete based on a large number of studies. Further, they proposed the constitutive models $[5,6]$. Zheng et al. added glass fiber, polypropylene fiber, and polyacrylonitrile fiber into concrete and investigated its axial compression performance. His research found that the axial compressive strength of concrete increases first and then decreases while the peak strain increases continuously [7]. Huang et al. added steel fiber into ultra-high-performance concrete (UHPC) and found that both the tensile strength and strain of UHPC are enhanced with the increase of the fiber content. Besides, the number of cracks on the surface of the specimen increased simultaneously [8]. Ali et al. added glass fiber into recycled aggregate concrete and found that the bending resistance of concrete improved [9]. Guo et al. found the fracture mechanical behaviors of concrete would be enhanced [10]. Kodur et al. (2003) [11] observed the strength change of concrete with and without the addition of fiber into concrete after it was exposed to high temperatures. They found that concrete with fiber effectively enhanced the fire resistance. At the same temperature, the strength of fiber concrete is greater than that of plain concrete. Many researchers have reached a similar conclusion in that the material strength, ductility, and impact resistance can be significantly improved by adding randomly distributed steel fibers into concrete [12-15]. In the development and application of fiber-reinforced concrete, Kearsley and Wainwright (2002) [16] showed that the compressive strength of fiber-reinforced concrete decreases exponentially with the decrease of the density. Ismail et al. (2010) [17] conducted experimental research on the mechanical properties of ordinary concrete after the application of high temperatures. When the temperature did not exceed $300{ }^{\circ} \mathrm{C}$, the compressive strength of high-temperature concrete changed little or even increased. With the further increase of the temperature, the compressive strength of concrete decreased rapidly. When the temperature reached $800{ }^{\circ} \mathrm{C}$, the concrete basically lost its bearing capacity. Ren, xue et al. (2016) [18] found that an increasing temperature generally leads to a decrease in the dynamic strength and impact toughness of basalt fiber-reinforced concrete for a given impact velocity, while the dynamic strength and impact toughness increase with the impact velocity for a given temperature. Novák and Kohoutková (2017) proposed the procedure of testing hybrid-reinforced concrete and found that both the tensile and compressive strength of hybrid-reinforced concrete decrease with increasing temperature [19]. The effect of the loading rate on the concrete behavior has also been extensively studied [20-24], and the split-Hopkinson bar might be the most widely used experimental equipment. Khosravani and Weinberg (2018) reviewed the dynamic characteristic of concrete under dynamic loads induced by using a split-Hopkinson bar [20].

On the basis of the literature review above, high temperatures can damage the microand meso-structure and result in a generalized mechanical decay. Eventually, it results in detrimental effects at the structural level due to concrete spalling in the case of fire. Thus, this study proposes a basalt fiber-reinforced concrete, and the thermal and dynamic mechanical behavior was studied after thermal and cooling treatments were applied. 


\section{Materials and Methods}

Compared with traditional concrete, basalt fiber-reinforced concrete has the advantages of higher tensile strength and less cracking. The main mechanism is that after basalt fiber is added, basalt fiber exerts its high tensile strength characteristics, and then shows the overall strength of basalt fiber-reinforced concrete. At the same time, basalt fiber-reinforced concrete has better anti-cracking advantages compared with traditional concrete, and its thermal and chemical properties are also different from traditional concrete. In addition, as mentioned in the literature section, i.e., introduction section, concrete has been used in many scenarios with high temperatures in modern society. Thus, this study focused on the development of a fiber-reinforced concrete, and then the proposed fiber-reinforced concrete was tested with high temperatures, cooling methods, and dynamic loading to obtain its thermal and dynamic behaviors.

\subsection{The Main Component of Basalt Fiber-Reinforced Concrete}

Basalt fiber-reinforced concrete is made up of constituent materials, like Portland cement, coal ash, aggregates, silica fume, water superplasticizer, and basalt fiber.

(1) Portland cement

Portland cement is produced by a local company in Yunnan Province, China. The density of the Portland cement is $2908 \mathrm{~kg} / \mathrm{m}^{3}$ while the other parameters are listed in Table 1.

Table 1. The component of the Portland cement.

\begin{tabular}{ccccccc}
\hline Chemical Component & $\mathrm{SiO}_{2}$ & $\mathrm{CaO}$ & $\mathrm{MgO}_{3}$ & $\mathrm{Fe}_{2} \mathrm{O}$ & $\mathrm{NaO}$ & $\mathrm{K}_{2} \mathrm{O}$ \\
\hline$\%$ & 20.7 & 64.0 & 1.82 & 4.41 & 0.2 & 1.2 \\
\hline
\end{tabular}

(2) Silica fume

When silica fume meets water, it will quickly dissolve. The solution is rich in $\mathrm{SiO}_{2}$. When the solution is added to concrete, it will hydrate with the calcium ions in the concrete and produce $\mathrm{CSH}$ gel with the $\mathrm{Ca}(\mathrm{OH})_{2}$ in the concrete. The silicon powder used in this experiment was produced by Zhengzhou Rongchangsheng Silicon Powder Co., Ltd., from Zhengzhou City, China, and its particle size is $0.15 \sim 0.2 \mu \mathrm{m}$.

(3) Fly ash

Fly ash can reduce the use of cement, increase the fluidity of concrete, reduce the reaction heat of the hydration reaction, and fill the gap of concrete, and then improve the strength of concrete. The fly ash was produced by Zhengzhou Borun Refractory Material Co., Ltd. from Zhengzhou City, China (Figure 1a). The density is $2 \mathrm{~g} / \mathrm{cm}^{3}$, and the main chemical components include $\mathrm{SiO}_{2}, \mathrm{Al}_{2} \mathrm{O}_{3}, \mathrm{Fe}_{2} \mathrm{O}_{3}, \mathrm{CaO}$, etc.

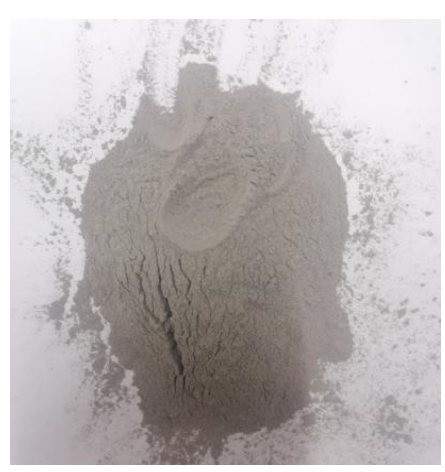

(a) Fly ash

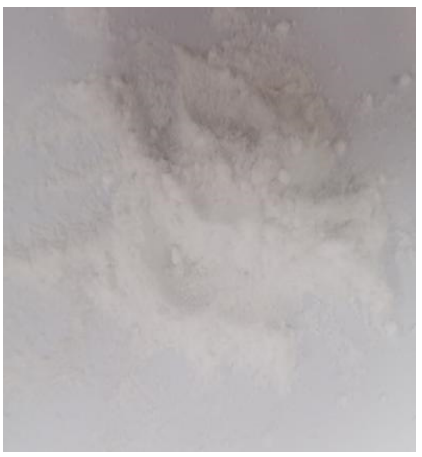

(b) Superplasticizer

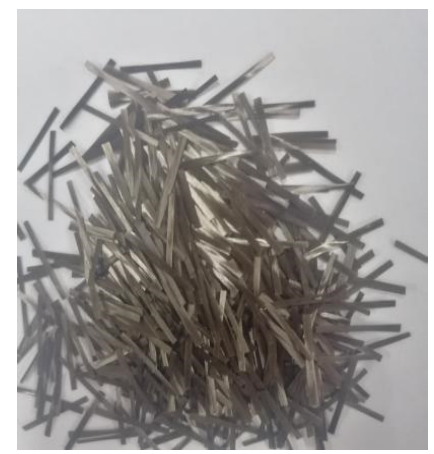

(c) Chopped basalt fiber

Figure 1. Raw material for the concrete experiment.

(4) Coarse aggregate 
The selected Kunming limestone crushed stone has a particle size of less than $20 \mathrm{~mm}$, a density of $2737 \mathrm{~kg} / \mathrm{m}^{3}$, and a mud content of $0.35 \%$.

(5) Fine aggregate

High-quality Kunming River sand was selected, with a density of $2645 \mathrm{~kg} / \mathrm{m}^{3}$ and a mud content of $1.7 \%$.

(6) Water

All water used was laboratory tap water.

(7) Superplasticizer

Shandong Wanshan Chemical Co., Ltd. from Weifang City, China, was selected to produce a high-efficiency water reducing agent, i.e., superplasticizer, which is a white powder with a water reduction rate of $20 \%$, as shown in Figure $1 \mathrm{~b}$.

(8) Chopped basalt fiber

Chopped basalt fiber produced by Huixiang Co., Ltd. from Kunming City, China, was selected, with a chopped length of $6 \mathrm{~mm}$ and a density of $2660 \mathrm{~kg} / \mathrm{m}^{3}$, as shown in Figure 1c.

\subsection{Specimen Preparation and Processing}

\subsubsection{Specimen Preparation}

In this experiment, the $\mathrm{C} 30$ ordinary concrete and basalt fiber-reinforced concrete were used to investigate their mechanical properties. The size of the concrete cube specimen was $100 \mathrm{~mm} \times 100 \mathrm{~mm} \times 100 \mathrm{~mm}$, and the size of the cylinder specimen that was used in the static experiment was $75 \mathrm{~mm}$ in diameter and $100 \mathrm{~mm}$ in height, while the size of the cylinder specimen that was used in the SHPB dynamic experiment was $75 \mathrm{~mm}$ in diameter and $40 \mathrm{~mm}$ in height [25]. According to the relevant regulations of countries, the proportion of concrete is shown in the Table 2.

Table 2. Proportions of concrete mix (unit $\mathrm{kg} / \mathrm{m}^{3}$ ).

\begin{tabular}{cccccccc}
\hline Specimens & Water & $\begin{array}{c}\text { Portland } \\
\text { Cement }\end{array}$ & Fly Ash & $\begin{array}{c}\text { Silica } \\
\text { Fume }\end{array}$ & Sand & Aggregation & $\begin{array}{c}\text { Superplasticizer } \\
\text { Basalt } \\
\text { Fiber }\end{array}$ \\
\hline $\begin{array}{c}\text { Ordinary } \\
\text { concrete C30 } \\
\text { Basalt }\end{array}$ & 190 & 292.5 & 135 & 22.5 & 680 & 1110 & 9 \\
$\begin{array}{c}\text { fiber-reinforced } \\
\text { concrete C30 }\end{array}$ & 190 & 292.5 & 135 & 22.5 & 680 & 1110 & 9 \\
\hline
\end{tabular}

To ensure concrete specimens meet the requirements of the experiment and the relevant documents and regulations in China, production equipment, including an electronic scale, concrete vibrator, concrete mixer, mold, shovel, mud knife, and sprinkling, were used in the specimen preparation process.

According to the requirements of the experiment, first, the concrete fibers were soaked in water so that they were evenly distributed in the concrete, and the required materials were weighed: cement, fly ash, silica fume, crushed stone, water, river sand, water reducing agent, and basalt fiber, according to the proportions. Then, the weighed dry aggregate excluding water and water reducing agent were placed into the mixer and mixed for 3-5 min to obtain a better uniformity. Then, the weighed water and water reducing agent was placed into the mixer and mixed for 3-5 min. After mixing, the concrete was removed with a shovel, and placed into a $30 \mathrm{~cm} \times 30 \mathrm{~cm} \times 30 \mathrm{~cm}$ mold and a $10 \mathrm{~cm} \times 10 \mathrm{~cm} \times 10 \mathrm{~cm}$ mold, and compacted. Finally, a trowel was used to compact the concrete placed in the mold to maintain a level top surface. After one day and night, the mold was removed and the specimen was taken out. The specimen was placed in a $10 \mathrm{~cm} \times 10 \mathrm{~cm} \times 10 \mathrm{~cm}$ curing box for curing, and the wrapped in a $30 \mathrm{~cm} \times 30 \mathrm{~cm} \times 30 \mathrm{~cm}$ plastic wrap. The specimen was sprayed with water for curing every day, and the temperature was maintained for 28 days at $20 \sim 25^{\circ} \mathrm{C}$. Figure 2 shows the process of preparing the concrete. 


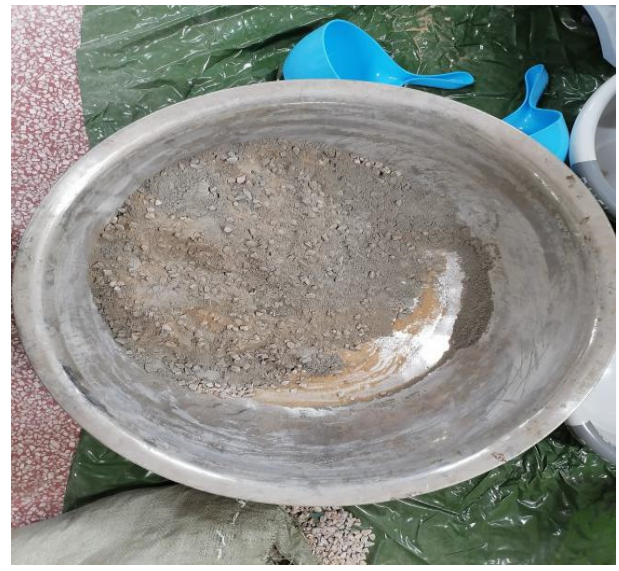

(a) Matching

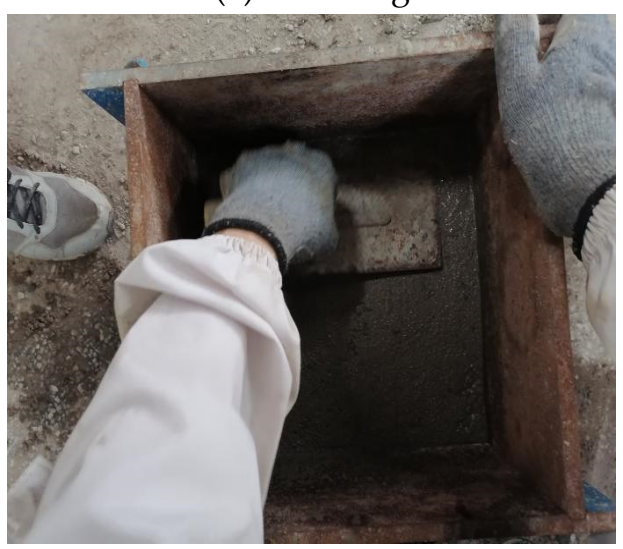

(c) Compaction

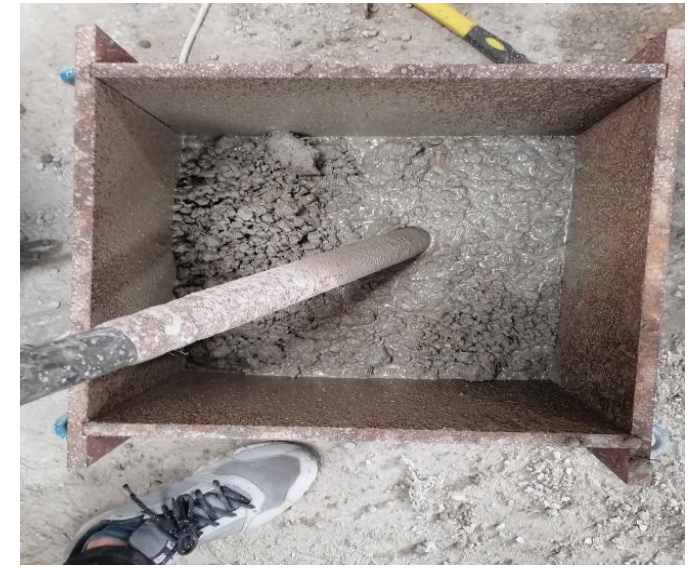

(b) Vibration

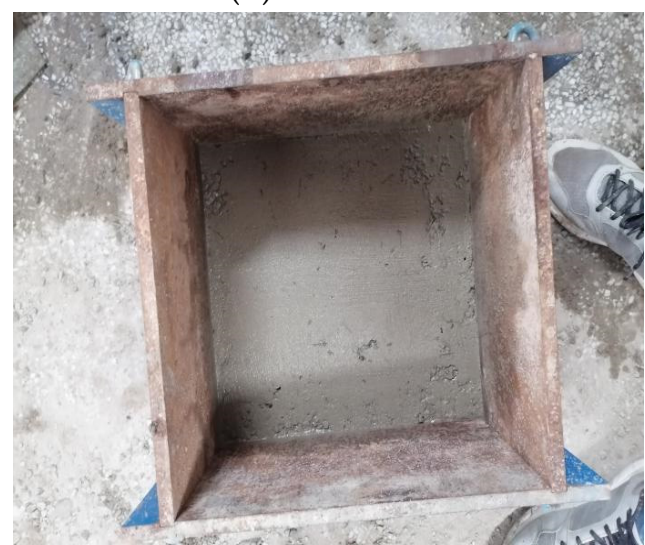

(d) Module

Figure 2. Concrete preparation process.

\subsubsection{Specimen Processing}

\section{(1) Coring process}

The coring machine used in this coring was a SC-200 automatic coring machine, and the drill used was a diamond drill with a diameter of $\varnothing 75$, as shown in Figure 3a. First, the cured concrete was fixed in the coring machine, and the drill bit was moved slowly when it was about to approach the concrete, and automatic work advancement was selected for coring. The coring speed was $5 \mathrm{~mm} / \mathrm{min}$.

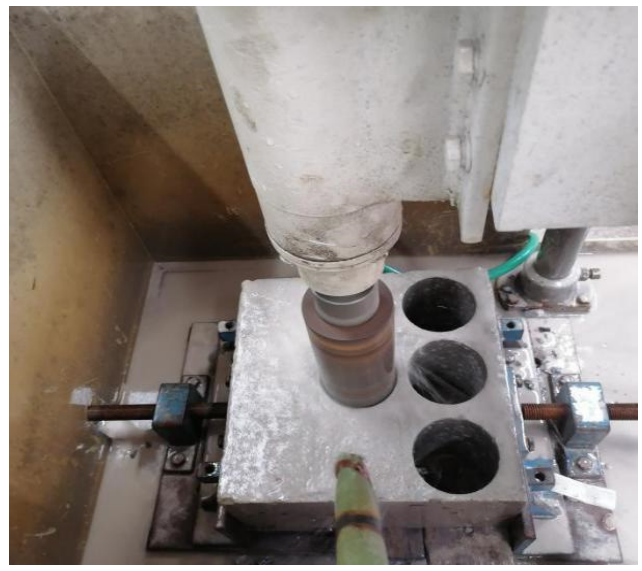

(a) Coring

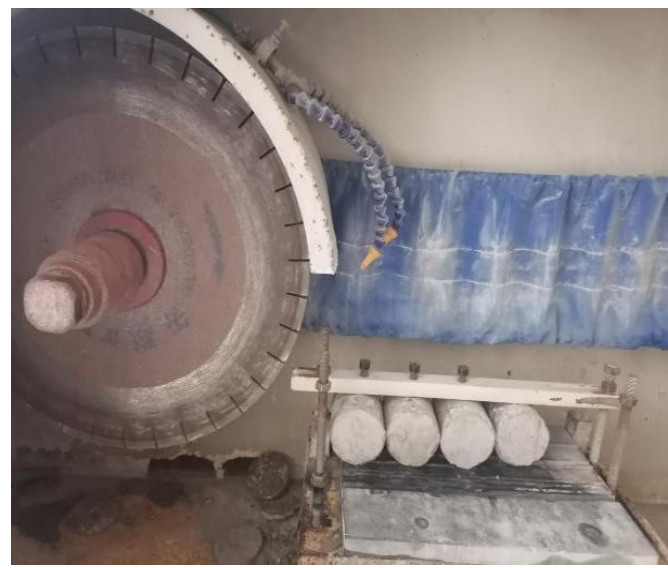

(b) Cutting

Figure 3. Cont. 


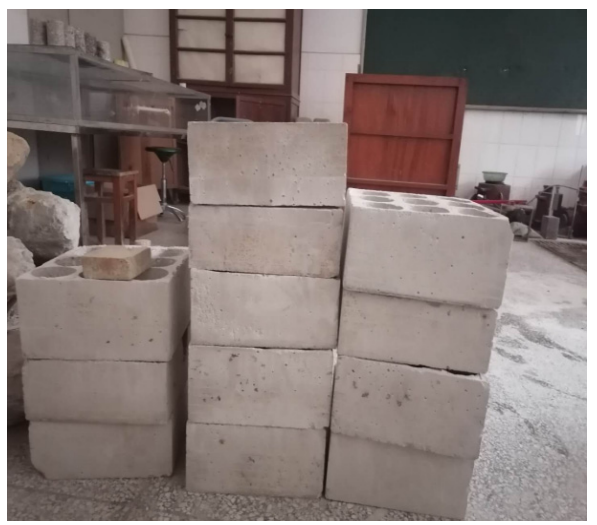

(c) Concrete cubic

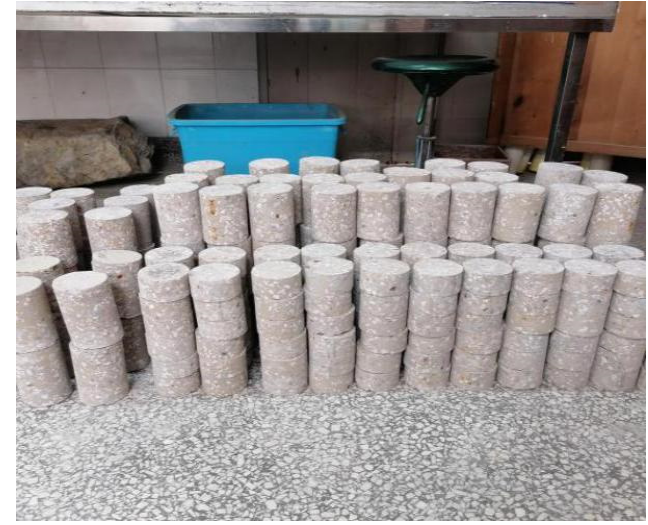

(d) Concrete cylinder

Figure 3. Processing process of the concrete specimen.

\section{(2) Cutting}

The cutting machine used in this cutting was a SCQ-300 automatic cutting machine as shown in Figure $3 b$, the saw blade adopted a diamond blade, and the cutting speed was $5 \mathrm{~mm} / \mathrm{min}$. Figure $3 \mathrm{c}$, d show the concrete cubic after coring and the concrete cylinders, respectively.

(3) Polishing

When the cutting of the specimens finished, the specimens were coarse. The specimens' surface was polished until smooth, in order to ensure these specimens were standard and thus increased the security in the later experiment.

\subsection{Heating and Cooling Treatments}

The heating equipment used in this experiment was a xw7L-12 box-type resistance furnace, the voltage was $220 \mathrm{~V}$, and the power was $3 \mathrm{KW} 5 \mathrm{KW}$. The maximum heating temperature was $1200^{\circ} \mathrm{C}$, and the furnace size was $120 \mathrm{~mm} \times 200 \mathrm{~mm} \times 300 \mathrm{~mm}$. Because concrete is a thermally inert material, when the heating speed is too fast, the temperature difference between the inside and outside of the concrete will be too large, and the moisture in the concrete will not evaporate in time, causing the concrete to burst during the heating process. Therefore, the heating rate selected was $0.5{ }^{\circ} \mathrm{C} / \mathrm{min}$, and the temperature was maintained for $2 \mathrm{~h}$ after reaching the predetermined temperature, so that the inside reached the corresponding temperature. After taking it out with crucible tongs, an infrared detector (AR872-D) was used to measure the temperature to ensure that the concrete reached a predetermined temperature.

This experiment used two cooling methods: natural cooling and water cooling, which required placing concrete in air and water for cooling.

\subsection{Experimental Equipment}

\subsubsection{Static Compressive Experimental Equipment}

The uniaxial compression experiment was carried out on the YAW-2000C constant stress pressure experimental machine, as shown in Figure 4a. The maximum experimental force was $2000 \mathrm{kN}$, the experimental force range was $0 \sim 2000 \mathrm{kN}$, the rated voltage was $380 \mathrm{~V} / 220 \mathrm{~V}$, and the motor power was $1.5 \mathrm{KW}$. The working environment temperature was $10 \sim 35{ }^{\circ} \mathrm{C}$, and there was no vibration, no corrosive media, and no magnetic field interference in the working environment. The strain instrument adopted is shown in Figure $4 \mathrm{~b}$, with a measuring accuracy of $0.01 \mathrm{~mm}$. 


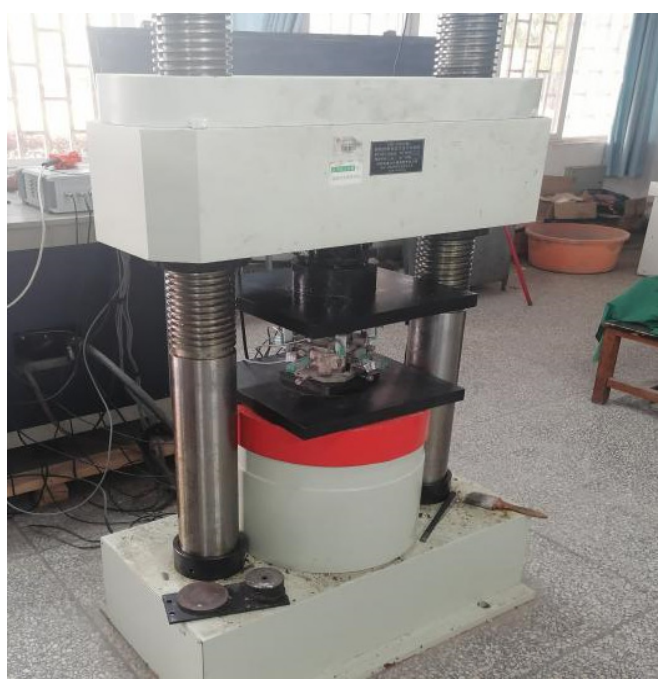

(a) YAW-2000C constant stress pressure experimental machine

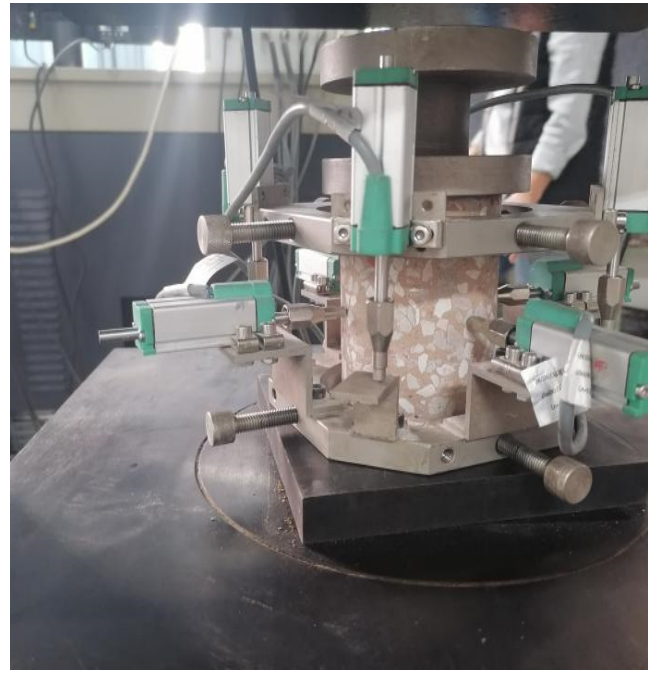

(b) Static compressive strain instrument

Figure 4. Static compressive experimental equipment.

\subsubsection{Dynamic Experimental Equipment}

The dynamic compressive experiment used the Split-Hopkinson pressure bar (SHPB) of the Laboratory of Kunming University of Science and Technology. The Split-Hopkinson pressure bar system was shown in Figure 5. The diameter of the SHPB is $75 \mathrm{~mm}$. The length of the incident bar and transmitted bar is $2 \mathrm{~m}$, the density is $7795 \mathrm{~kg} / \mathrm{m}^{3}$, the elastic modulus is $210 \mathrm{GPa}$, the Poisson's ratio is 0.286 , the loading rate is $0 \sim 50 \mathrm{~m} / \mathrm{s}$, and the accuracy is $0.1 \mathrm{~m} / \mathrm{s}$. The bullet is spindle shaped. The strain gauge is attached to the center of the bar, and the distance from the incident bar and the transmission bar is consistent. At the same time, it is equipped with a strain gauge, oscilloscope, and tachometer.

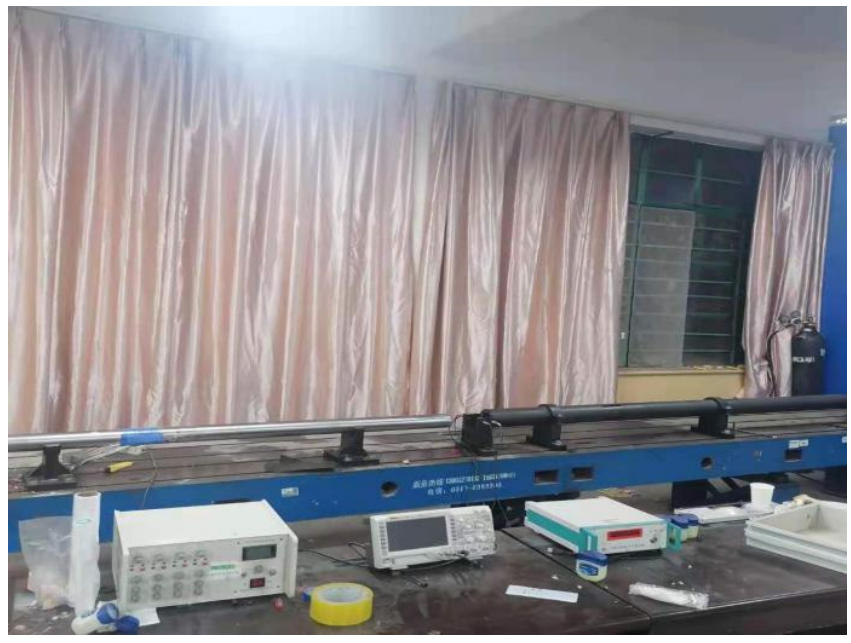

Figure 5. Split-Hopkinson pressure bar system.

\section{Experimental Results and Discussion}

\subsection{Basic Physical Parameters}

In this section, the changes of the basic physical parameters including the concrete mass, wave velocity, and color under various high temperatures $\left(200,400,600\right.$, and $\left.800{ }^{\circ} \mathrm{C}\right)$ were observed. 


\subsubsection{Effect of High Temperature on Mass}

Based on the high-temperature treatment, the mass loss of the ordinary concrete and the basalt fiber-reinforced concrete is presented in Tables 3 and 4 .

Table 3. The mass loss of ordinary concrete.

\begin{tabular}{cccccc}
\hline Temperature/ ${ }^{\circ} \mathbf{C}$ & Diameter/mm & Hight/mm & $\begin{array}{c}\text { Mass before } \\
\text { Heat/g }\end{array}$ & $\begin{array}{c}\text { Mass } \\
\text { after } \\
\text { Heat/g }\end{array}$ & Mass Loss/\% \\
\hline \multirow{2}{*}{200} & 75 & 40.0 & 427 & 391 & 0.060702576 \\
& 75 & 40.1 & 429 & 398 & 0.052027972 \\
& 75 & 40.0 & 427 & 395 & 0.053957845 \\
\hline \multirow{2}{*}{400} & 75 & 40.0 & 426 & 385 & 0.069295775 \\
& 75 & 40.3 & 436 & 400 & 0.059449541 \\
600 & 75 & 39.9 & 422 & 381 & 0.069952607 \\
\hline \multirow{2}{*}{800} & 75 & 40.3 & 438 & 381 & 0.09369863 \\
& 75 & 39.9 & 416 & 360 & 0.096923077 \\
& 75 & 40.0 & 421 & 364 & 0.097482185 \\
\hline & 75 & 39.8 & 413 & 320 & 0.162130751 \\
& 75 & 39.8 & 415 & 324 & 0.157879518 \\
& 39.9 & 416 & 333 & 0.143653846 \\
\hline
\end{tabular}

Table 4. The mass loss of basalt fiber-reinforced concrete.

\begin{tabular}{cccccc}
\hline Temperature/ ${ }^{\circ} \mathbf{C}$ & Diameter/mm & Hight/mm & $\begin{array}{c}\text { Mass before } \\
\text { Heat/g }\end{array}$ & $\begin{array}{c}\text { Mass } \\
\text { after } \\
\text { Heat/g }\end{array}$ & Mass Loss/\% \\
\hline \multirow{2}{*}{200} & 75 & 40.2 & 429 & 398 & 0.052027972 \\
& 75 & 40.1 & 423 & 398 & 0.042553191 \\
400 & 75 & 39.8 & 426 & 397 & 0.049014085 \\
\hline \multirow{2}{*}{600} & 75 & 40.4 & 434 & 395 & 0.064700461 \\
& 75 & 40.3 & 433 & 396 & 0.061524249 \\
& 75 & 40.2 & 433 & 399 & 0.056535797 \\
\hline \multirow{2}{*}{800} & 75 & 40.5 & 438 & 381 & 0.09369863 \\
& 75 & 39.8 & 416 & 360 & 0.096923077 \\
& 75 & 39.7 & 421 & 364 & 0.097482185 \\
\hline 75 & 40.3 & 441 & 369 & 0.11755102 \\
& 75 & 40.2 & 445 & 375 & 0.113258427 \\
& 75 & 426 & 367 & 0.09971831 \\
\hline
\end{tabular}

The high-temperature treatment test results show that the mass of the two kinds of concrete decreases with the increase of the temperature. The mass loss of concrete is mainly due to the evaporation of free water before the temperature reaches $200{ }^{\circ} \mathrm{C}$. When the temperature reaches $400{ }^{\circ} \mathrm{C}$, the bound water in the concrete begins to precipitate, while the $\mathrm{CaCO}_{3}$ in the concrete will resolve into $\mathrm{CaO}$ and $\mathrm{CO}_{2}$ when the temperature reaches $800{ }^{\circ} \mathrm{C}$.

\subsubsection{Effect of High Temperature on Wave Velocity}

The wave velocity is usually considered as a typical indicator of the integrity of the internal physical and mechanical properties of concrete materials. However, the velocity parameter is directly influenced by the temperature. In this experiment, the ZBL-U510 nonmetallic ultrasonic detector was placed on both sides of the concrete specimen to measure the wave velocity after the heating temperature treatment. The results are shown in Table 5. 
Table 5. The wave velocity of concretes after heating.

\begin{tabular}{|c|c|c|c|c|}
\hline Type & $25^{\circ} \mathrm{C}$ & $200^{\circ} \mathrm{C}$ & $400{ }^{\circ} \mathrm{C}$ & $600^{\circ} \mathrm{C}$ \\
\hline Ordinary concrete wave velocity & $2243 \mathrm{~m} / \mathrm{s}$ & $2196 \mathrm{~m} / \mathrm{s}$ & $2013 \mathrm{~m} / \mathrm{s}$ & $1997 \mathrm{~m} / \mathrm{s}$ \\
\hline Basalt fiber-reinforced concrete wave velocity & $2365 \mathrm{~m} / \mathrm{s}$ & $2226 \mathrm{~m} / \mathrm{s}$ & $2078 \mathrm{~m} / \mathrm{s}$ & $2047 \mathrm{~m} / \mathrm{s}$ \\
\hline
\end{tabular}

It can be seen from the above experimental results recorded in the Table 5 that the wave velocity of ordinary concrete and basalt fiber-reinforced concrete is descending with the temperature rise. Thus, it can be seen that the high temperature produces a detrimental effect for the mechanical property of concrete.

\subsubsection{Effect of High Temperature on Color}

Figures 6 and 7 illustrate the ordinary concrete and basalt fiber-reinforced concrete heated to $200,400,600$, and $800{ }^{\circ} \mathrm{C}$, respectively.

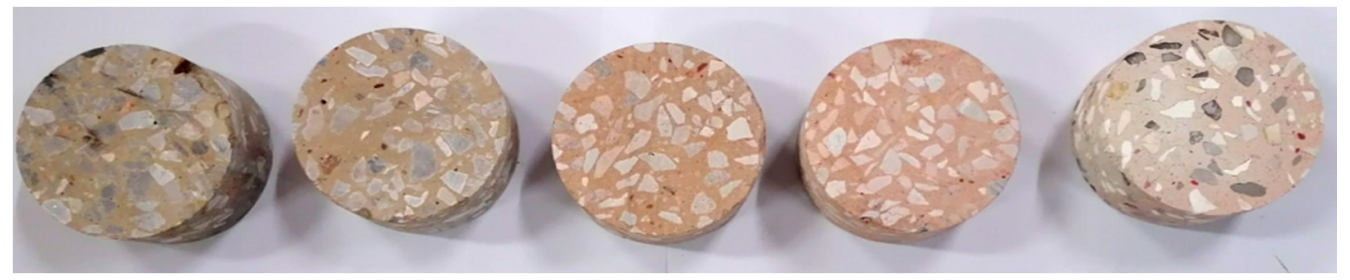
(a) $25^{\circ} \mathrm{C}$
(b) $200{ }^{\circ} \mathrm{C}$
(c) $400{ }^{\circ} \mathrm{C}$
(d) $600{ }^{\circ} \mathrm{C}$
(e) $800{ }^{\circ} \mathrm{C}$

Figure 6. Ordinary concrete.

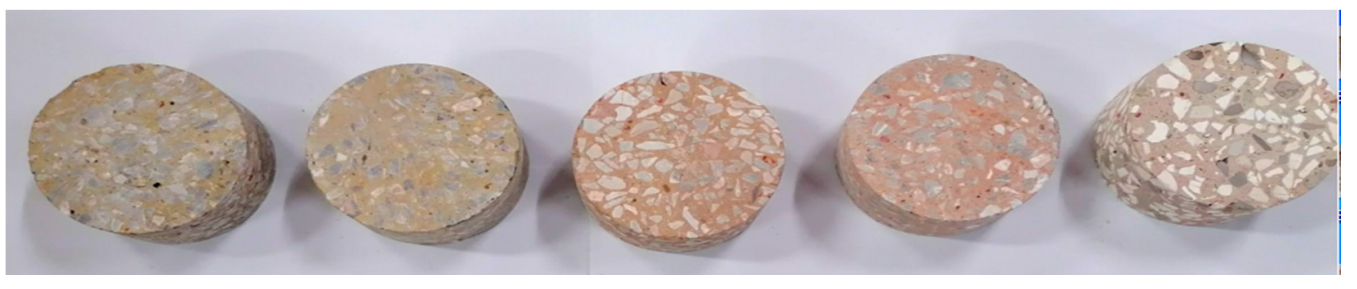
(a) $25^{\circ} \mathrm{C}$
(b) $200{ }^{\circ} \mathrm{C}$
(c) $400{ }^{\circ} \mathrm{C}$
(d) $600{ }^{\circ} \mathrm{C}$
(e) $800^{\circ} \mathrm{C}$

Figure 7. Basalt fiber-reinforced concrete.

A color change of the specimen was observed after natural cooling, as shown in Figures 6 and 7. It can be seen from Figures 6 and 7 that the specimen was dark blue at room temperature $\left(25^{\circ} \mathrm{C}\right)$. As the temperature increased, the color of the specimen gradually turned red. When the temperature reached $600{ }^{\circ} \mathrm{C}$, the specimen changed from dark blue to pink. When the temperature continued to rise, the test piece gradually began to turn white-brown, because as the temperature increased, the additives in the concrete underwent physical and chemical changes.

\subsubsection{Comparison between Ordinary Concrete and Basalt Fiber-Reinforced Concrete}

As shown in Tables 3 and 4, the density of basalt fiber-reinforced concrete is higher than ordinary concrete. In addition, as can be seen in Figure 8, although the overall mass loss rate declined, the mass loss rate of basalt fiber-reinforced concrete was lower at every temperature compared with ordinary concrete. 


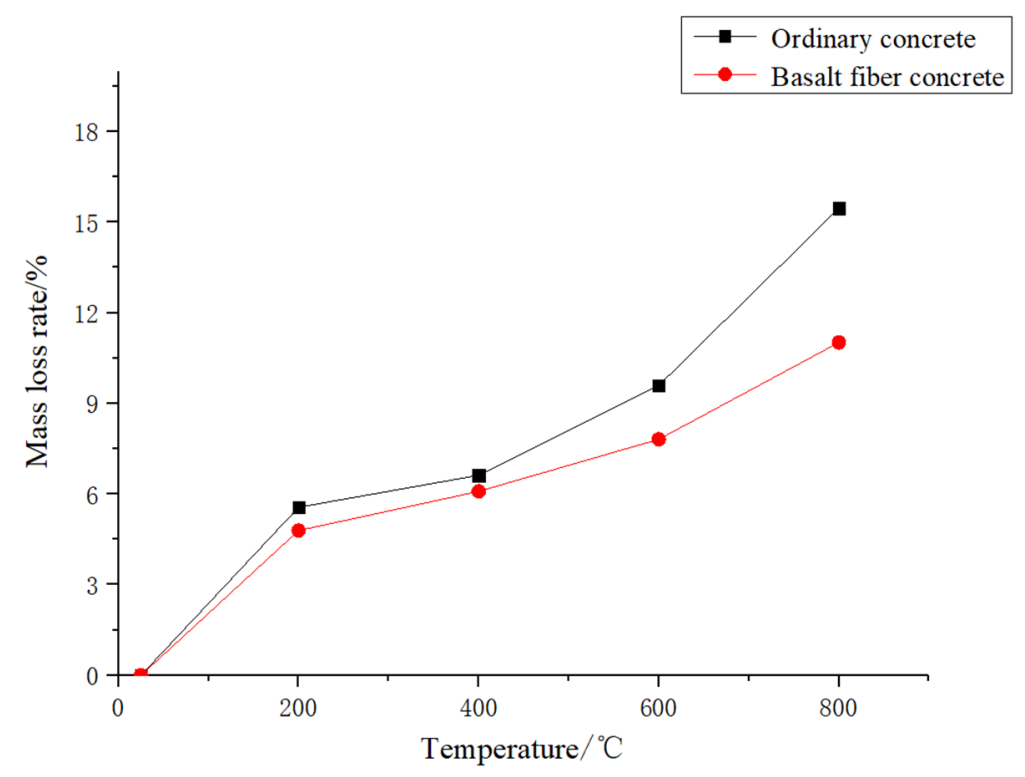

Figure 8. The mass loss rate of the two concretes after heating.

Figure 9 shows, at the same temperature, that the wave velocity of basalt fiberreinforced concrete is higher than ordinary concrete. Here, the compactness of basalt fiber-reinforced concrete is better than ordinary concrete and the effect of the high temperature on the basalt fiber-reinforced concrete is more slight than ordinary concrete.

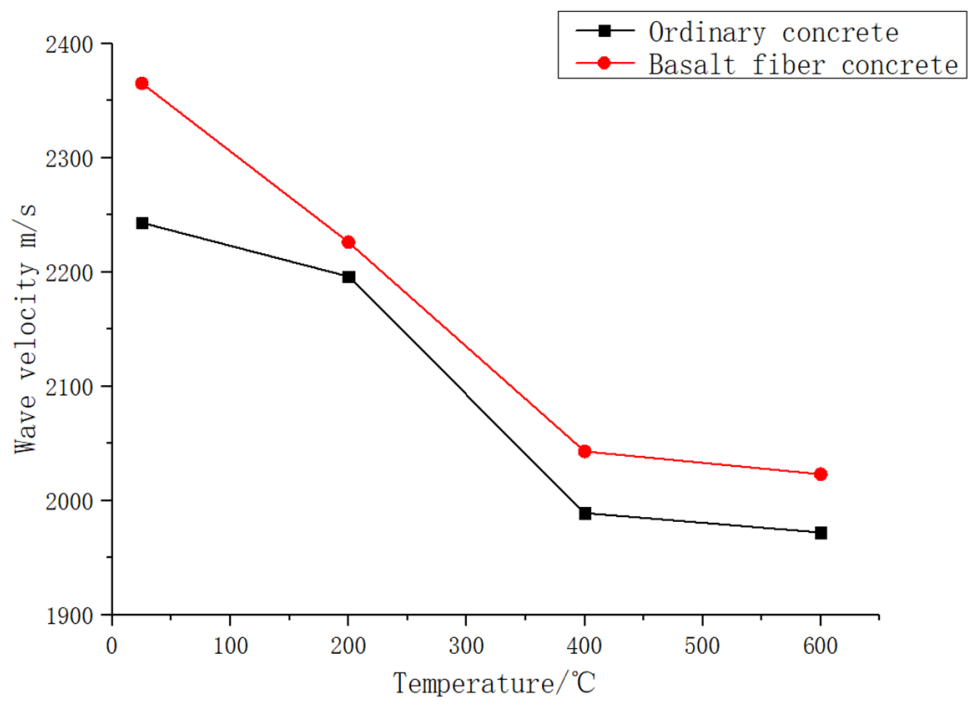

Figure 9. The wave velocity comparison of the two concretes after heating.

Figures 6 and 7 show that, compared with ordinary concrete, the change of color in basalt fiber-reinforced concrete performed a little hysteresis after heating. In addition, during heating, the number of cracks of basalt fiber-reinforced concrete increased more than ordinary concrete.

\subsection{Static Compressive Strength}

The research on the static mechanical properties of concrete is the most important and basic research on the properties of concrete. Its failure pattern is simple, the failure mechanism is clear, and it is easy for researchers to analyze. In addition, the research on the static mechanical properties of concrete is an important index to measure the strength and bearing capacity of concrete. 
In this research, ordinary concrete (PC) and basalt fiber-reinforced concrete (fiber volume parameter is $0.2 \%$ ), with a diameter of $\varnothing 75 \mathrm{~mm}$ and height $100 \mathrm{~mm}$, were heated to $200,400,600$, and $800{ }^{\circ} \mathrm{C}$, respectively, to carry out a static mechanical contrast experiment and compare it with the static compressive strength of concrete at room temperature, and carry out a comparative study on its broken form. This paper will analyze and discuss the strength variation trend of basalt fiber in concrete under the action of high temperatures, and briefly describes the strengthening mechanism of basalt fiber on concrete strength. At the same time, two cooling methods were adopted to analyze the influence of different cooling methods on the concrete strength under high-temperature conditions.

\subsubsection{Effect of High Temperature on Static Compressive Strength}

The trend of the two concretes' strength at a high temperature is similar. For air cooling, the experiment results are shown in Tables 6 and 7.

Table 6. The static compressive strength of ordinary concrete in air cooling.

\begin{tabular}{cccc}
\hline Temperature $/{ }^{\circ} \mathbf{C}$ & Hight $/ \mathbf{m m}$ & Mass/g & Strength/Mpa \\
\hline \multirow{2}{*}{25} & 100.0 & 1072 & 32.3 \\
& 99.8 & 1067 & 30.8 \\
& 99.7 & 1064 & 31.6 \\
\hline \multirow{2}{*}{200} & 100.4 & 978 & 36.9 \\
& 100.3 & 995 & 34.7 \\
& 99.7 & 987 & 37.8 \\
\hline \multirow{2}{*}{400} & 99.5 & 962 & 23.9 \\
& 100.3 & 1003 & 19.6 \\
& 99.3 & 952 & 23.6 \\
\hline \multirow{2}{*}{600} & 99.2 & 948 & 16.1 \\
& 99.7 & 900 & 15.7 \\
& 99.5 & 910 & 14.9 \\
\hline \multirow{2}{*}{800} & 100.4 & 807 & 8.6 \\
& 99.6 & 810 & 7.4 \\
& 100.5 & 836 & 7.5 \\
\hline
\end{tabular}

Table 7. The static compressive strength of basalt fiber-reinforced concrete in air cooling.

\begin{tabular}{cccc}
\hline Temperature ${ }^{\circ} \mathbf{C}$ & High/mm & Mass/g & Strength/Mpa \\
\hline \multirow{2}{*}{25} & 100.3 & 1072 & 37.5 \\
& 99.6 & 1057 & 35.7 \\
& 99.9 & 1065 & 34.8 \\
\hline \multirow{2}{*}{200} & 99.8 & 995 & 43.0 \\
& 100.7 & 995 & 42.6 \\
& 99.4 & 992 & 39.7 \\
\hline \multirow{2}{*}{400} & 99.9 & 987 & 30.6 \\
& 100.0 & 990 & 32.1 \\
& 100.6 & 997 & 25.8 \\
\hline \multirow{2}{*}{600} & 99.7 & 977 & 17.6 \\
& 99.9 & 977 & 19.5 \\
& 99.8 & 960 & 15.4 \\
\hline \multirow{2}{*}{800} & 100.8 & 922 & 11.5 \\
& 99.7 & 937 & 4.3 \\
& 100.2 & 917 & 10.8 \\
\hline
\end{tabular}

Although the overall trend of the strength of the two concretes decreases with the temperature increasing, the concrete strength increases when the temperature increases within $25 \sim 200{ }^{\circ} \mathrm{C}$ and reaches a peak when the temperature reaches $200{ }^{\circ} \mathrm{C}$. The concrete 
strength begins to decrease with the further increase of the temperature. When the temperature reaches $400{ }^{\circ} \mathrm{C}$, the strength of ordinary concrete decreases $25 \%$ than the strength at room temperature while the strength of basalt fiber-reinforced concrete decreases $7.2 \%$ than the strength at room temperature. When the temperature reaches $600{ }^{\circ} \mathrm{C}$, the strength of ordinary concrete decreases $49.3 \%$ compared to the strength in room temperature while the strength of basalt fiber-reinforced concrete decreases $53.1 \%$ compared to the strength at room temperature. When the temperature reaches $800^{\circ} \mathrm{C}$, the strength of ordinary concrete decreases $75.8 \%$ compared to the strength at room temperature while the strength of basalt fiber-reinforced concrete decreases $68.9 \%$ compared to the strength at room temperature.

The reason for this phenomenon is that, when the temperature is less than $200{ }^{\circ} \mathrm{C}$, the cracks inside concrete are fewer because of thermal expansion and cold contraction; therefore, the static compressive strength is improved. With the further increase of the temperature, the bound water inside the concrete begins to precipitate, and the static compressive strength decreases rapidly. When the temperature reaches $800{ }^{\circ} \mathrm{C}$, the $\mathrm{CaCO}_{3}$ inside the aggregate of cement paste begins to resolve into $\mathrm{CaO}$, so that the concrete loses its bearing capacity.

The failure patterns of the two kinds of concrete subjected to high temperatures under air cooling are shown as follows:

At room temperature and $200{ }^{\circ} \mathrm{C}$, the two concretes were subjected to axial pressure, and concrete specimens without confining pressure extended along the longitudinal and the discontinuous tension failure was increased. With the increase of compression, the cracks gradually penetrated and caused the surface to break, and spalling occurred locally, causing the concrete to lose its bearing capacity. When the temperature increased further, the bound water in the concrete began to precipitate, the internal cracks gradually developed and penetrated, and concrete showed failure patterns of " $/$ ", "V", and " $\mathrm{X}$ ".

\subsubsection{Effect of Two Cooling Methods on Static Compressive Strength}

The experimental results of the compressive strength of the two concretes in water cooling are shown in Tables 8 and 9.

Table 8. The static compressive strength of ordinary concrete in water cooling.

\begin{tabular}{cccc}
\hline Temperature $^{\circ} \mathbf{C}$ & Hight $/ \mathbf{m m}$ & Mass/g & Strength/Mpa \\
\hline \multirow{2}{*}{25} & 100.1 & 1089 & 32.5 \\
& 99.7 & 1097 & 31.0 \\
& 99.6 & 1084 & 30.9 \\
\hline \multirow{2}{*}{200} & 99.3 & 1015 & 28.7 \\
& 100.5 & 1026 & 33.5 \\
& 99.8 & 1087 & 29.6 \\
\hline \multirow{2}{*}{400} & 99.7 & 985 & 17.5 \\
& 100.2 & 1026 & 16.9 \\
& 100.4 & 972 & 26 \\
\hline \multirow{2}{*}{600} & 99.6 & 968 & 11.6 \\
& 99.3 & 925 & 9.8 \\
& 99.9 & 936 & 12.6 \\
\hline \multirow{2}{*}{800} & 100.5 & 826 & 3.5 \\
& 99.8 & 834 & 2.6 \\
& 100.1 & 857 & 3.9 \\
\hline
\end{tabular}


Table 9. The static compressive strength of basalt fiber-reinforced concrete in water cooling.

\begin{tabular}{cccc}
\hline Temperature $/{ }^{\circ} \mathbf{C}$ & Hight $/ \mathbf{m m}$ & Mass/g & Strength/Mpa \\
\hline 25 & 100.6 & 1101 & 37.5 \\
25 & 99.7 & 1058 & 35.7 \\
25 & 99.9 & 1069 & 34.8 \\
200 & 99.5 & 1021 & 33.6 \\
200 & 100.2 & 1016 & 19.5 \\
200 & 99.3 & 1032 & 36.4 \\
400 & 99.5 & 1006 & 21.3 \\
400 & 100.1 & 1012 & 22.5 \\
400 & 100.7 & 997 & 20.6 \\
600 & 99.9 & 996 & 15.4 \\
600 & 99.4 & 994 & 13.3 \\
600 & 99.8 & 984 & 14.8 \\
800 & 100.3 & 953 & 4.7 \\
800 & 99.8 & 967 & 4.5 \\
800 & 100.1 & 945 & 4.9 \\
\hline
\end{tabular}

Through the analysis of the experimental data, compared with air cooling in the same conditions, the strength of ordinary concrete declined by $19.4 \%, 22.2 \%, 25.5 \%$, and $35 \%$ at $200,400,600$, and $800{ }^{\circ} \mathrm{C}$, respectively, while the strength of basalt fiber-reinforced concrete declined by $9.9 \%, 27.2 \%, 12.5 \%$, and $35.5 \%$ at $200,400,600$, and $800{ }^{\circ} \mathrm{C}$, respectively. The static compressive strength of concrete after cooling in the air is greater than that after cooling in water.

After the concrete subjected to high temperature was cooled by water, a temperature difference existed between the interior and exterior of the concrete, and the temperature difference was larger with the increase of the temperature. Therefore, the static compressive strength decreased rapidly after the high-temperature concrete was cooled by water. When the temperature reached $600{ }^{\circ} \mathrm{C}$, the bound water inside the concrete began to precipitate, the concrete cooled by water underwent rehydration, and therefore the compressive strength was enhanced partly. However, due to further expansion of the temperature difference, the static compressive strength of the high-temperature concrete continued to decline.

Compared with Figures 10 and 11, the failure patterns of the two concretes under water cooling are shown as follows:

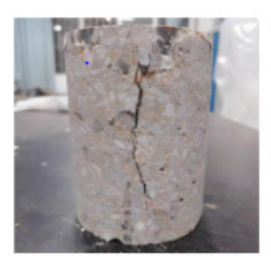

(a) $25^{\circ} \mathrm{C}$

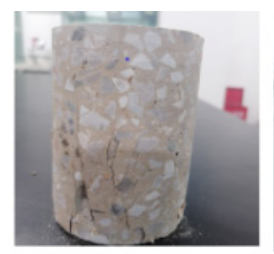

(b) $200^{\circ} \mathrm{C}$

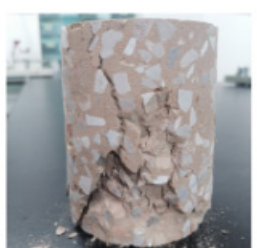

(c) $400{ }^{\circ} \mathrm{C}$

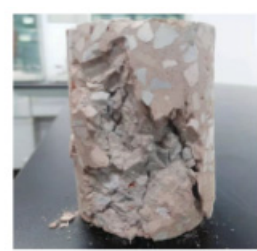

(d) $600{ }^{\circ} \mathrm{C}$

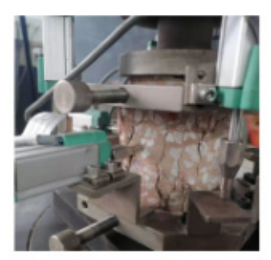

(e) $800^{\circ} \mathrm{C}$

Figure 10. The failure pattern of ordinary concrete in air cooling.

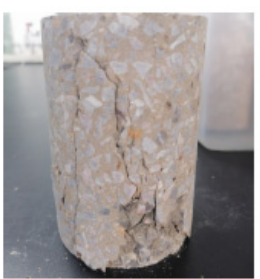

(a) $25^{\circ} \mathrm{C}$

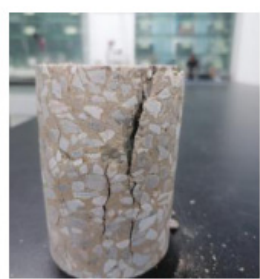

(b) $200^{\circ} \mathrm{C}$

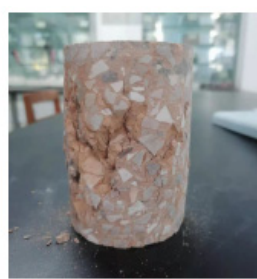

(c) $400{ }^{\circ} \mathrm{C}$

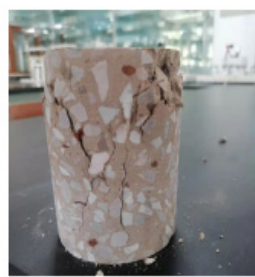

(d) $600{ }^{\circ} \mathrm{C}$

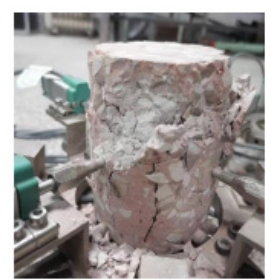

(e) $800{ }^{\circ} \mathrm{C}$

Figure 11. The failure pattern of basalt fiber-reinforced concrete in air cooling. 
It can be seen from the contrast between Figures 12 and 13, the fracture of the two kinds of concrete specimens for the water-cooled is bigger than that for the air-cooled at the same heating temperature. This is attributed to the effect of water cooling, which results in the formation of a large number of severe cracks inside the specimen during rapid cooling.

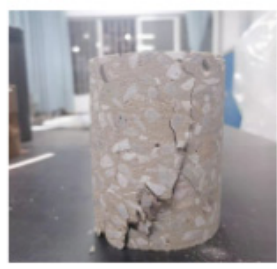

(a) $25{ }^{\circ} \mathrm{C}$

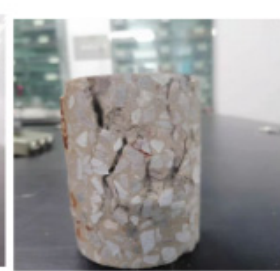

(b) $200{ }^{\circ} \mathrm{C}$

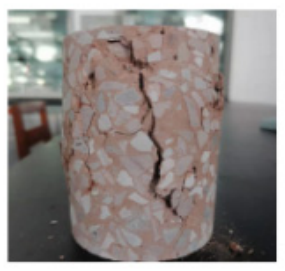

(c) $400{ }^{\circ} \mathrm{C}$

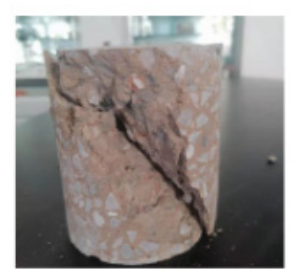

(d) $600{ }^{\circ} \mathrm{C}$

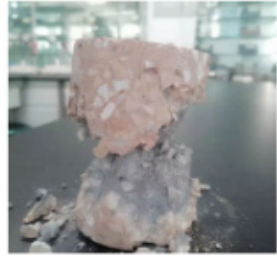

(e) $800{ }^{\circ} \mathrm{C}$

Figure 12. The failure pattern of ordinary concrete in water cooling.

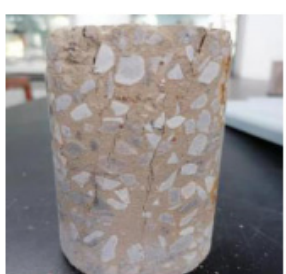

(a) $25^{\circ} \mathrm{C}$

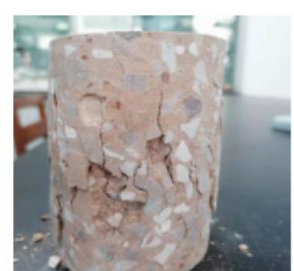

(b) $200{ }^{\circ} \mathrm{C}$

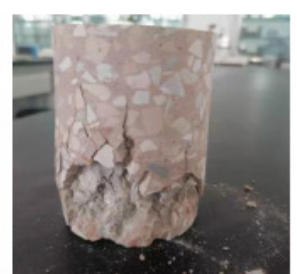

(c) $400{ }^{\circ} \mathrm{C}$

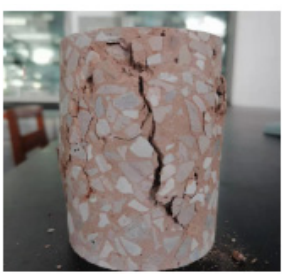

(d) $600{ }^{\circ} \mathrm{C}$

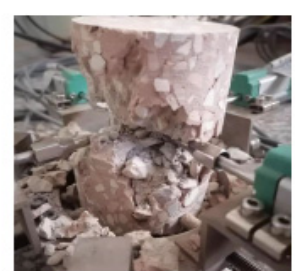

(e) $800{ }^{\circ} \mathrm{C}$

Figure 13. The failure pattern of basalt fiber-reinforced concrete in water cooling.

\subsubsection{Comparison of Static Compressive Stress-Strain Curves}

The stress-strain curves of concrete show three stages, including the linear rising stage, nonlinear stage of crack development, and decay stage after the arriving peak [26].

The failure of concretes under static compression is mainly due to the initiation and development of cracks whose positions are concentrated on the joints of aggregates and cement additives. Inside concrete, original cracks are formed in the process of concrete pouring and solidifying. The concrete began to crack locally in order to release the stress and avoid stress concentration when it was subjected to slow-motion static stress. In this process, only some certain locations were destroyed; therefore, the energy released was less. In the compressive stage of concrete, the concrete was observed to be an elastic material and therefore the stress-strain curve is linear in this stage.

With the further increase of the static load, the cracks inside concrete developed and intact cracks formed from the joints of the aggregates and mortar, and the concrete lost its stability gradually. In this stage, the cracks stop developing with the halt of the static compressive load and the strength of the concrete reached a maximum, and the stress-strain curve is nonlinear.

During the stage of the stress-strain curve declining, as the bearing capacity of concrete is lost gradually, the gradient of the stress-strain curve is small. The stress-strain curves of the experimental results agree well with the above three stages.

In Figure 14, the stress-strain curves of the two kinds of concretes in compression under static loading are plotted after water cooling and air cooling. The addition of the basalt fiber, maximum temperature, and cooling methods significantly affected the concrete behavior. 


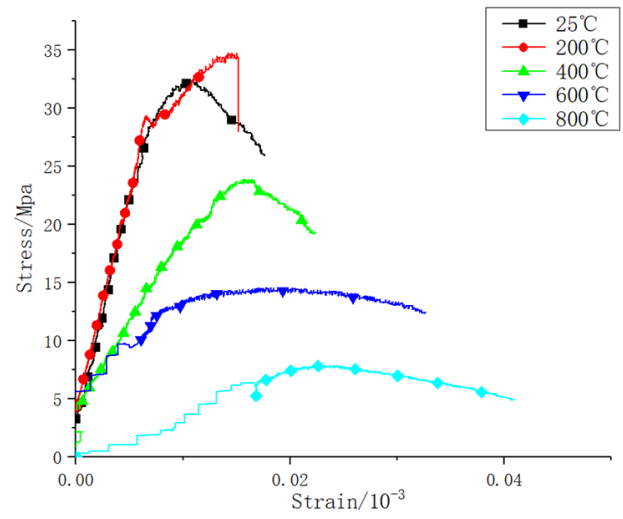

(a) Stress-strain curve of ordinary concrete in air cooling

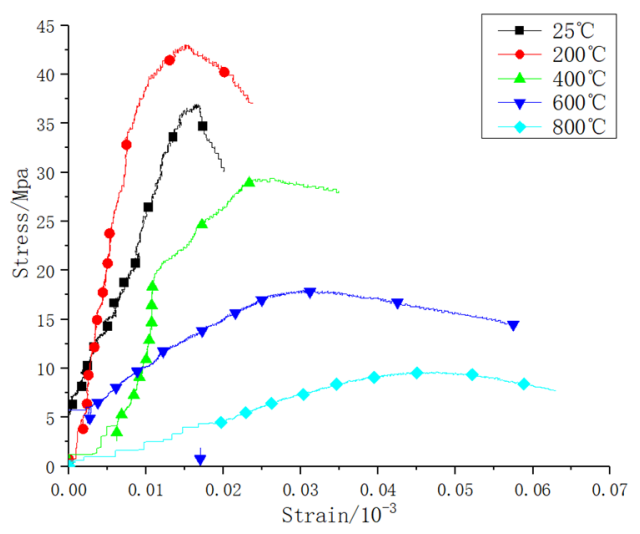

(c) Stress-strain curve of basalt fiberreinforced concrete in air cooling

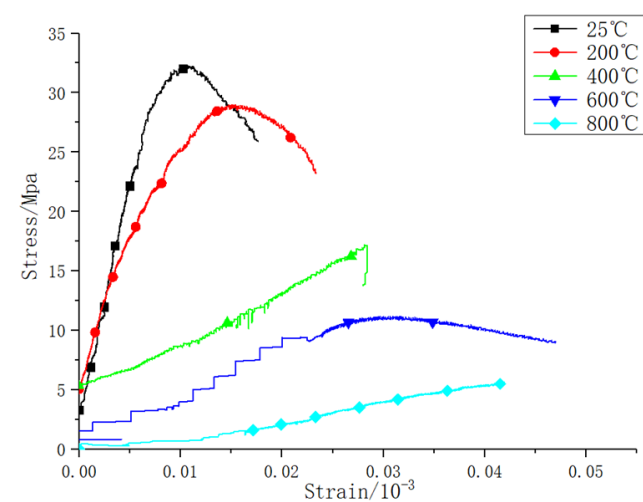

(b) Stress-strain curve of ordinary concrete in water cooling

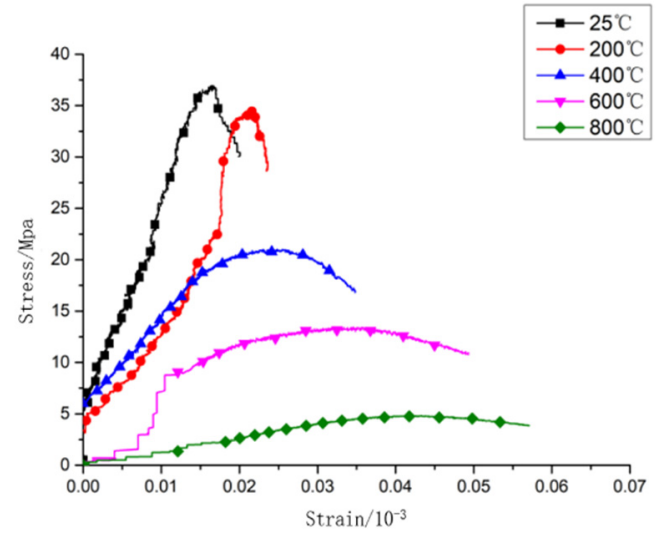

(d) Stress-strain curve of basalt fiberreinforced concrete in water cooling

Figure 14. Static compressive stress-strain curves of two kinds of concretes.

Under the same conditions, the compressive strength of basalt fiber-reinforced concrete is bigger than that of ordinary concrete. Besides, the higher the maximum temperature, the greater the reduction in the compressive strength. In addition, the static compressive strength of concrete after cooling in air is greater than that after cooling in water. In other words, water cooling is more detrimental to the compressive strength than air cooling.

\subsubsection{The Static Constitutive Models of Basalt Fiber-Reinforced Concrete}

There is significant meaning to the investigation of the constitutive models of concrete, as they could be used to study the concrete structure and nonlinear analysis [27]. The static compressive strength was tested in the experiment by raising the temperature of basalt fiber-reinforced concrete and cooling it in air or water. A reasonable constitutive model of basalt fiber-reinforced concrete was chosen to provide feasible suggestions for the practical application in engineering [28]. The parameters of this constitutive model were determined by the experimental results.

According to the experimental results, the static compressive strength of concrete could be impacted by high temperature. Therefore, the function expression of the strength-temperature constitutive model established through static compressive strength is as follows:

$$
F=t_{1}+t_{2} T+t_{3} T^{2}+t_{3} T^{3}
$$

F-Static compressive strength (Mpa).

$\mathrm{T}$-Temperature $\left({ }^{\circ} \mathrm{C}\right)$. 
On account of the function Equation (1), the fitting curve for the compressive strengthtemperature relationship of basalt fiber-reinforced in air cooling was showed in Figure 15, and the fitting parameters were recorded in Table 10.

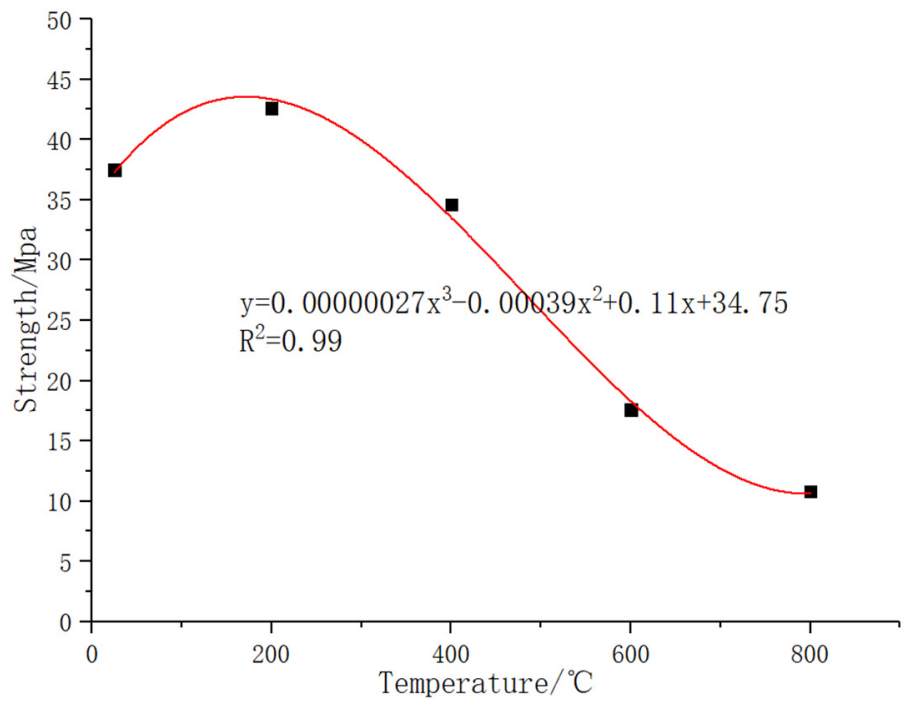

Figure 15. Static compression of basalt fiber-reinforced concrete in air cooling.

Table 10. The fitting parameters of the static compressive strength of basalt fiber-reinforced concrete in air cooling.

\begin{tabular}{ccccc}
\hline Parameters & $\mathbf{t}_{\mathbf{1}}$ & $\mathbf{t}_{\mathbf{2}}$ & $\mathbf{t}_{\mathbf{3}}$ & $\mathbf{t}_{\mathbf{4}}$ \\
\hline Basalt fiber-reinforced concrete & 34.75 & 0.11 & $-3.9 \times 10^{-4}$ & $2.7 \times 10^{-7}$ \\
\hline
\end{tabular}

The expression of the static compressive strength of basalt fiber-reinforced concrete in air cooling is as follows:

$$
f=34.75-0.11 \mathrm{~T}-0.00039 \mathrm{~T}^{2}+0.00000027 \mathrm{~T}^{3}
$$

$\mathrm{R}^{2}=0.99$.

On account of the function Equation (1), the fitting graph of basalt fiber-reinforced in water cooling was showed in Figure 16, and the fitting parameters were recorded in Table 11.

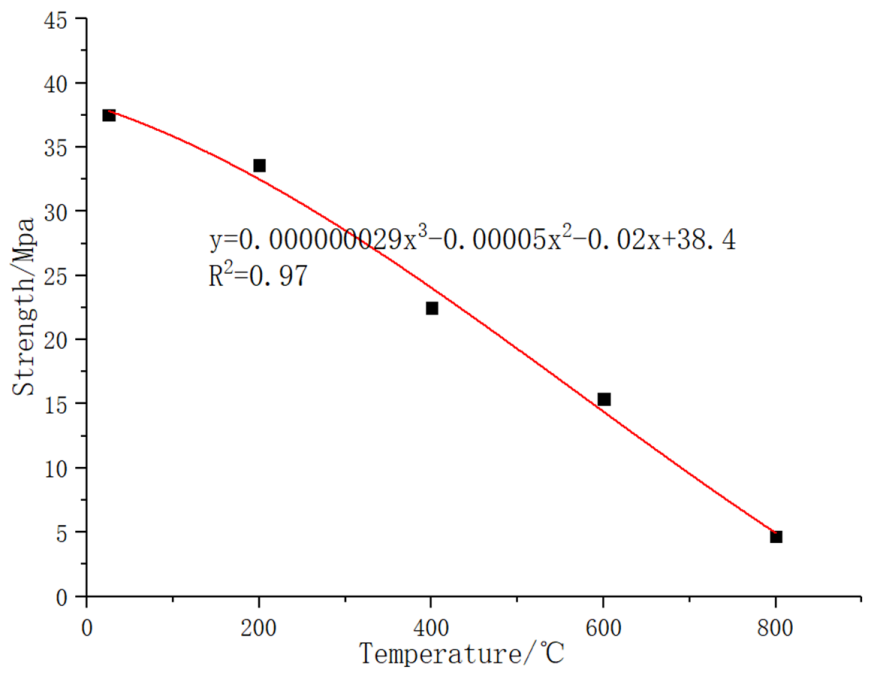

Figure 16. Static compression of basalt fiber-reinforced concrete in water cooling. 
Table 11. The fitting parameters of the static compressive strength of basalt fiber-reinforced concrete in water cooling.

\begin{tabular}{ccccc}
\hline Parameters & $\mathbf{t}_{\mathbf{1}}$ & $\mathbf{t}_{\mathbf{2}}$ & $\mathbf{t}_{\mathbf{3}}$ & $\mathbf{t}_{\mathbf{4}}$ \\
\hline Basalt fiber-reinforced concrete & 38.4 & -0.02 & $-5 \times 10^{-5}$ & $2.9 \times 10^{-8}$ \\
\hline
\end{tabular}

The expression of the static compressive strength of basalt fiber-reinforced concrete in air cooling is as follows:

$$
\mathrm{f}=38.4-0.02 \mathrm{~T}-0.00005 \mathrm{~T}^{2}=0.000000029 \mathrm{~T}^{3}
$$

$\mathrm{R}^{2}=0.97$

\subsubsection{Comparison between Ordinary Concrete and Basalt Fiber-Reinforced Concrete}

According to the data of Tables 6 and 7, the curves of the compressive strength of the two kinds of concretes in the two cooling methods can be seen in Figure 17.

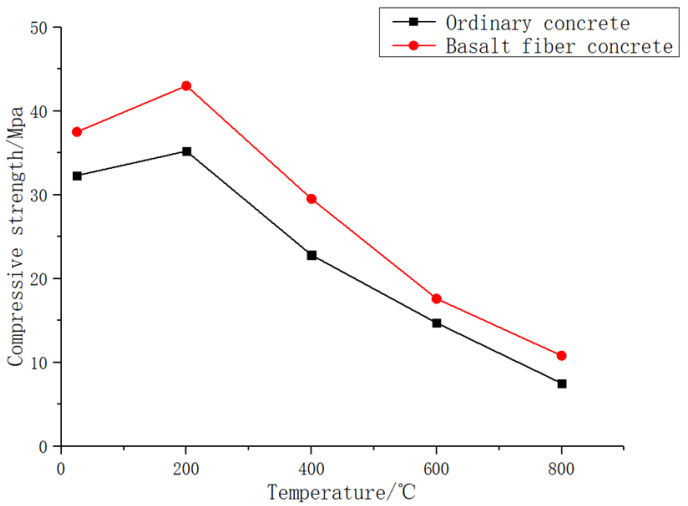

(a) Compressive strength curves of the two concretes in air cooling

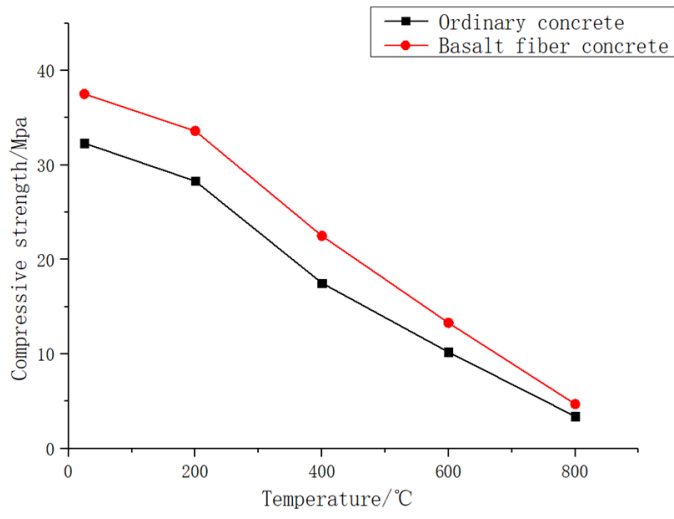

(b) Compressive strength curves of the two concretes in water cooling

Figure 17. Compressive strength curves of the two concretes in the two cooling methods.

In the air cooling method, the static compressive strength of basalt fiber-reinforced concrete is improved $16.1 \%, 16.6 \%, 39.9 \%, 12.1 \%$, and $25.6 \%$ more than ordinary concrete at room temperature, $200,400,600$, and $800{ }^{\circ} \mathrm{C}$, respectively. While, in the water method, the static compressive strength of basalt fiber-reinforced concrete is improved $16.1 \%, 14.3 \%$, $28.8 \%, 28.6 \%$, and $29.6 \%$ more than ordinary concrete at room temperature, $200,400,600$, and $800{ }^{\circ} \mathrm{C}$, respectively.

Form the comparison of the above data, the static compressive strength of basalt fiber-reinforced concrete is continuously improved compared to ordinary concrete with the increase of the temperature. Thus, it can be seen that the addition of basalt fiber to concrete can effectively reduce the effects of high temperatures on concrete and further improve the bearing capacity of concrete.

Through the comparison of the failure pattern, at the same temperature and using the same cooling method, the failure pattern of basalt fiber-reinforced concrete is superior to ordinary concrete. In the different cooling methods, the failure pattern of the two concrete specimens in air cooling is better than in water cooling.

\subsection{Dynamic Compressive Strength}

This section adopts the SHPB device with a diameter of $\Phi 75 \mathrm{~mm}$ mentioned in Section 2 to carry out the dynamic impact test of both ordinary concrete and basalt fiberreinforced concrete. The high-temperature electric furnace was used to heat the specimen to $200,400,600$, and $800^{\circ} \mathrm{C}$, and these high-temperature specimens were compared with 
the specimens at room temperature. At the same time, the air-cooling method and watercooling method were used to simulate the trend of the strength of the two concretes after the structure was subjected to fire fighting. In addition, three loading rates of 5.8, 7.8, and $9.8 \mathrm{~m} / \mathrm{s}$ were used to carry out the dynamic impact test and obtain the dynamic compressive strength, stress-strain curve, and failure pattern of the two concretes.

\subsubsection{Effect of the Strain Rate on the Dynamic Compressive Strength}

The stress-strain curve is an index reflecting the comprehensive performance of concrete. The characteristics of the curve reflect the characteristics of each stage of the whole process of internal structure failure of the concrete under an impact load.

The dynamic impact test data of the two concretes under three loading rates of 5.8, 7.8, and $9.8 \mathrm{~m} / \mathrm{s}$ are shown in Tables 12-17.

Table 12. The dynamic impact test of ordinary concrete on a loading rate of $5.8 \mathrm{~m} / \mathrm{s}$.

\begin{tabular}{ccccc}
\hline Temperature $/{ }^{\circ} \mathbf{C}$ & Hight $/ \mathbf{m m}$ & Mass/g & Strength/Mpa & Strain Rate/s \\
\hline \multirow{2}{*}{25} & 40.1 & 427 & 46.5 & 102 \\
& 40.3 & 429 & 42.3 & 98 \\
& 40.0 & 427 & 45.5 & 103 \\
\hline \multirow{2}{*}{200} & 40.2 & 391 & 57.9 & 117 \\
& 40.4 & 398 & 63.5 & 121 \\
400 & 40.1 & 395 & 49.5 & 113 \\
\hline \multirow{3}{*}{600} & 40.2 & 385 & 32.1 & 125 \\
& 40.4 & 400 & 34.2 & 147 \\
& 40.2 & 381 & 30.5 & 129 \\
\hline \multirow{2}{*}{800} & 40.0 & 381 & 25.8 & 146 \\
& 40.8 & 360 & 20.9 & 137 \\
& 40.3 & 364 & 18.5 & 115 \\
\hline & 40.6 & 320 & 9.3 & 156 \\
& 40.3 & 324 & 7.6 & 158 \\
\hline
\end{tabular}

Table 13. The dynamic impact test of ordinary concrete on a loading rate of $7.8 \mathrm{~m} / \mathrm{s}$.

\begin{tabular}{ccccc}
\hline Temperature $/{ }^{\circ} \mathbf{C}$ & Hight $/ \mathbf{m m}$ & Mass/g & Strength/Mpa & Strain Rate/s \\
\hline \multirow{2}{*}{25} & 40.0 & 436 & 52.5 & 132 \\
& 40.2 & 428 & 51.6 & 127 \\
& 39.9 & 427 & 55.9 & 136 \\
\hline \multirow{2}{*}{200} & 40.1 & 388 & 62.5 & 137 \\
& 40.3 & 395 & 60.8 & 135 \\
& 40.0 & 392 & 63.7 & 139 \\
\hline \multirow{2}{*}{400} & 40.1 & 382 & 37.5 & 151 \\
& 40.3 & 397 & 39.9 & 154 \\
600 & 40.1 & 378 & 38.2 & 159 \\
& 39.9 & 378 & 28.6 & 163 \\
& 40.7 & 357 & 26.9 & 167 \\
\hline \multirow{2}{*}{800} & 40.2 & 361 & 27.8 & 175 \\
& 40.5 & 317 & 11.8 & 187 \\
& 40.2 & 321 & 12.3 & 186 \\
\hline
\end{tabular}


Table 14. The dynamic impact test of ordinary concrete on a loading rate of $9.8 \mathrm{~m} / \mathrm{s}$.

\begin{tabular}{ccccc}
\hline Temperature $/{ }^{\circ} \mathbf{C}$ & Hight $/ \mathbf{m m}$ & Mass/g & Strength/Mpa & Strain Rate/s \\
\hline \multirow{2}{*}{25} & 40.1 & 391 & 65 & 163 \\
& 40.3 & 398 & 60.3 & 157 \\
& 40.0 & 395 & 67.9 & 165 \\
\hline \multirow{2}{*}{200} & 40.2 & 385 & 80 & 171 \\
& 40.4 & 400 & 78.6 & 173 \\
& 40.1 & 381 & 59.9 & 176 \\
\hline \multirow{3}{*}{400} & 40.2 & 381 & 53.2 & 197 \\
& 40.4 & 360 & 48.9 & 189 \\
600 & 40.2 & 364 & 49.7 & 187 \\
& 40.0 & 320 & 42.3 & 206 \\
& 40.8 & 324 & 37.5 & 198 \\
& 40.3 & 333 & 40.3 & 213 \\
\hline \multirow{3}{*}{800} & 40.6 & 391 & 17.6 & 228 \\
& 40.3 & 398 & 15.5 & 236 \\
\hline
\end{tabular}

Table 15. The dynamic impact test of basalt fiber-reinforced concrete on a loading rate of $5.8 \mathrm{~m} / \mathrm{s}$.

\begin{tabular}{|c|c|c|c|c|}
\hline Temperature $/{ }^{\circ} \mathrm{C}$ & Hight $/ \mathrm{mm}$ & Mass/g & Strength/Mpa & Strain Rate/s ${ }^{-1}$ \\
\hline \multirow{3}{*}{25} & 40.2 & 429 & 49.5 & 110 \\
\hline & 40.3 & 423 & 52.6 & 106 \\
\hline & 40.0 & 426 & 35.8 & 89 \\
\hline \multirow{3}{*}{200} & 40.2 & 396 & 69.5 & 115 \\
\hline & 40.4 & 398 & 67.5 & 113 \\
\hline & 40.1 & 397 & 72.1 & 126 \\
\hline \multirow{3}{*}{400} & 40.2 & 395 & 45.5 & 135 \\
\hline & 40.4 & 396 & 43.5 & 131 \\
\hline & 40.2 & 399 & 40.6 & 136 \\
\hline \multirow{3}{*}{600} & 40.0 & 381 & 25.6 & 143 \\
\hline & 40.8 & 360 & 23.5 & 145 \\
\hline & 40.3 & 364 & 27.8 & 152 \\
\hline \multirow{3}{*}{800} & 40.6 & 369 & 12.5 & 163 \\
\hline & 40.3 & 375 & 11.9 & 172 \\
\hline & 40.0 & 367 & 10.7 & 174 \\
\hline
\end{tabular}

It can be seen from Tables 12-17 that the strain rate significantly influences the strength of the specimen, regardless of the type of concrete and the impact velocities. Table 12 illustrates that the strength increases with the increase of the strain rate for the normal concrete. For the normal concrete at different impact velocities, i.e., Tables 13 and 14, the experimental results come to the same conclusion. In addition, for the basalt fiberreinforced concrete, it also demonstrates the same strain rate effect on strength.

Through the above experimental data, the stress-strain curves under various loading rates and at room temperature $\left(25^{\circ} \mathrm{C}\right), 200^{\circ} \mathrm{C}$, and $400^{\circ} \mathrm{C}$ are found as follows.

It can be seen from Figures 18 and 19 that the dynamic compressive strength of the two concretes increases with the increase of the loading rate. When the loading rate is $5.8 \mathrm{~m} / \mathrm{s}$, the strength of ordinary concrete at room temperature improves by $43.9 \%$ compared to the static load at the same temperature. The strengths of ordinary concrete improve $65.8 \%$ and $51 \%$ at 200 and $400{ }^{\circ} \mathrm{C}$, respectively, compared with the static load at the same temperature, while the strengths of basalt fiber-reinforced concrete improve by $32 \%, 61.6 \%$, and $41.7 \%$ at room temperature $\left(25^{\circ} \mathrm{C}\right), 200$, and $400^{\circ} \mathrm{C}$, respectively, compared with the static load at the same temperature. When the loading rate is $7.8 \mathrm{~m} / \mathrm{s}$, the strength of ordinary concrete improves by $62.5 \%, 69.5 \%$, and $56.9 \%$ at room temperature, 200 , and $400{ }^{\circ} \mathrm{C}$, respectively, 
compared with the static load at the same temperature, while the strengths of basalt fiberreinforced concrete improve by $73.2 \%, 77.8 \%$, and $69.6 \%$ at room temperature $\left(25^{\circ} \mathrm{C}\right), 200$, and $400{ }^{\circ} \mathrm{C}$, respectively, compared with the static load at the same temperature. When the loading rate is $9.8 \mathrm{~m} / \mathrm{s}$, the strength of ordinary concrete improves by $101 \%, 116 \%$, and $109 \%$ at room temperature, 200 , and $400{ }^{\circ} \mathrm{C}$, respectively, compared with the static load at the same temperature, while the strengths of basalt fiber-reinforced concrete improve by $140 \%, 155 \%$, and $169 \%$ at room temperature $\left(25^{\circ} \mathrm{C}\right), 200$, and $400{ }^{\circ} \mathrm{C}$, respectively, compared with the static load at the same temperature.

Table 16. The dynamic impact test of basalt fiber-reinforced concrete on a loading rate of $7.8 \mathrm{~m} / \mathrm{s}$.

\begin{tabular}{ccccc}
\hline Temperature $/{ }^{\circ} \mathbf{C}$ & Hight $/ \mathbf{m m}$ & Mass/g & Strength/Mpa & Strain Rate/s \\
\hline \multirow{2}{*}{25} & 40.5 & 433 & 70.5 & 152 \\
& 40.7 & 427 & 65.8 & 147 \\
& 40.5 & 430 & 72.4 & 156 \\
\hline \multirow{2}{*}{200} & 40.6 & 402 & 80.2 & 159 \\
& 40.3 & 402 & 90.8 & 157 \\
& 40.0 & 401 & 63.2 & 155 \\
\hline \multirow{3}{*}{400} & 40.0 & 399 & 53.8 & 162 \\
& 40.4 & 400 & 44.9 & 165 \\
600 & 40.1 & 403 & 50.3 & 168 \\
& 40.3 & 385 & 38.7 & 168 \\
& 40.8 & 364 & 36.5 & 171 \\
& 40.3 & 368 & 36.2 & 165 \\
\hline \multirow{3}{*}{800} & 40.6 & 373 & 11.4 & 185 \\
& 40.3 & 379 & 11.9 & 189 \\
\hline
\end{tabular}

Table 17. The dynamic impact test of basalt fiber-reinforced concrete on a loading rate of $9.8 \mathrm{~m} / \mathrm{s}$.

\begin{tabular}{ccccc}
\hline Temperature $/{ }^{\circ} \mathbf{C}$ & Hight $/ \mathbf{m m}$ & Mass/g & Strength/Mpa & Strain Rate/s \\
\hline \multirow{2}{*}{25} & 39.6 & 428 & 90.3 & 161 \\
& 40.2 & 425 & 87.6 & 165 \\
& 39.7 & 425 & 92.3 & 167 \\
\hline \multirow{2}{*}{200} & 40.2 & 397 & 110 & 171 \\
& 40.5 & 396 & 103.7 & 176 \\
& 39.4 & 397 & 107.9 & 174 \\
\hline \multirow{2}{*}{400} & 40.1 & 396 & 63.7 & 186 \\
& 40.3 & 397 & 75.9 & 189 \\
600 & 40.2 & 398 & 60.3 & 184 \\
\hline \multirow{3}{*}{60} & 39.1 & 382 & 47.5 & 192 \\
& 40.3 & 365 & 45.5 & 197 \\
& 40.2 & 367 & 32.1 & 196 \\
\hline \multirow{2}{*}{800} & 40.3 & 363 & 21.6 & 207 \\
& 40.0 & 377 & 19.8 & 217 \\
\hline
\end{tabular}




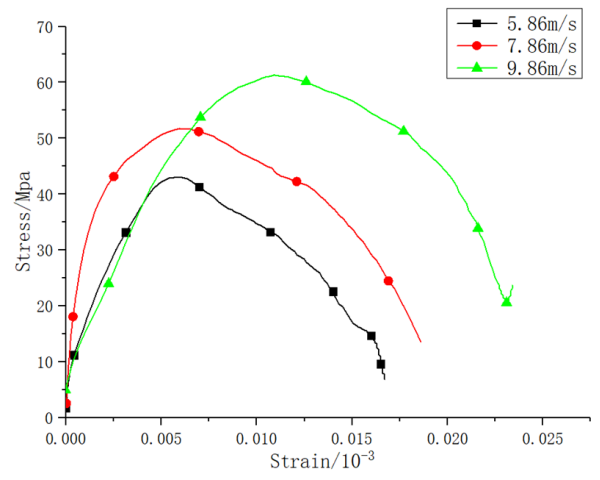

(a) $25^{\circ} \mathrm{C}$

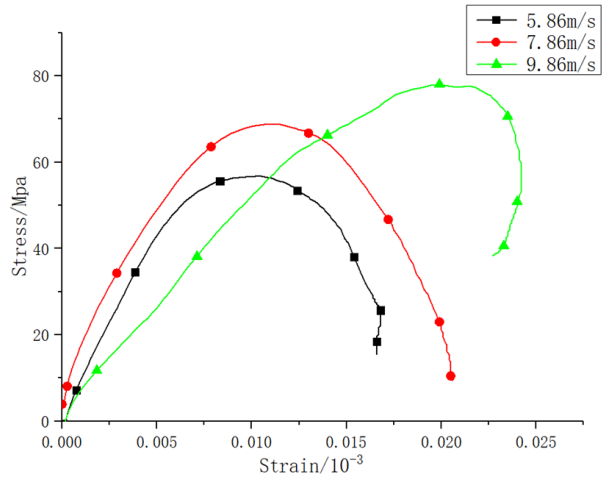

(b) $200{ }^{\circ} \mathrm{C}$

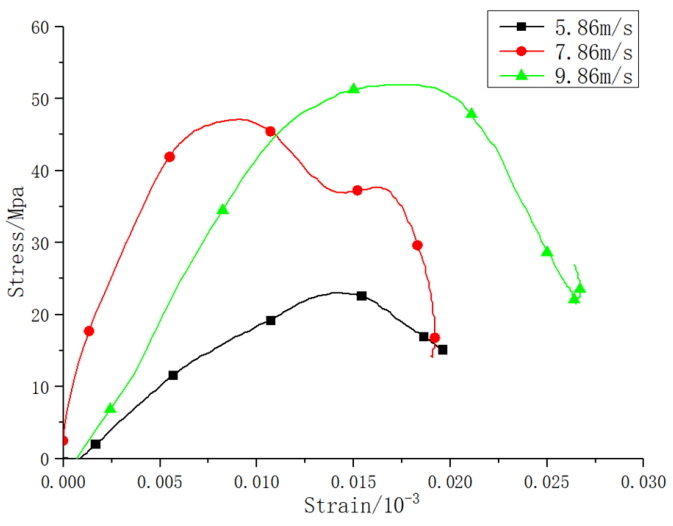

(c) $400{ }^{\circ} \mathrm{C}$

Figure 18. The stress-strain curve of ordinary concrete under three loading rates.

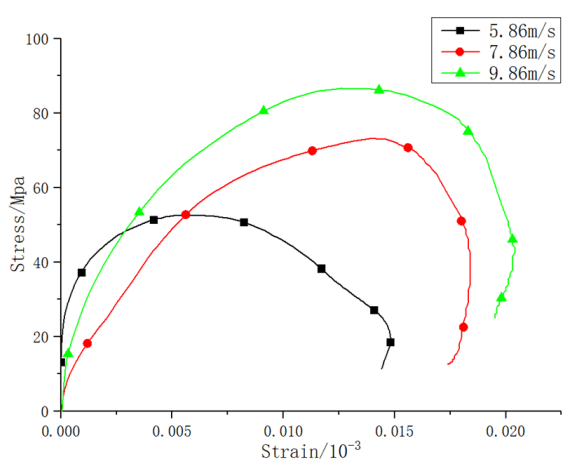

(a) $25{ }^{\circ} \mathrm{C}$

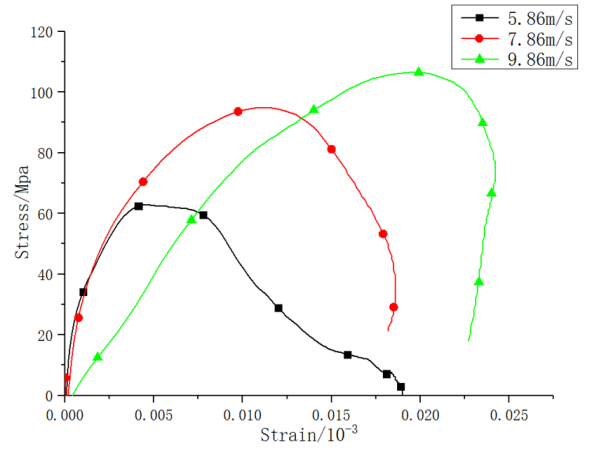

(b) $200{ }^{\circ} \mathrm{C}$

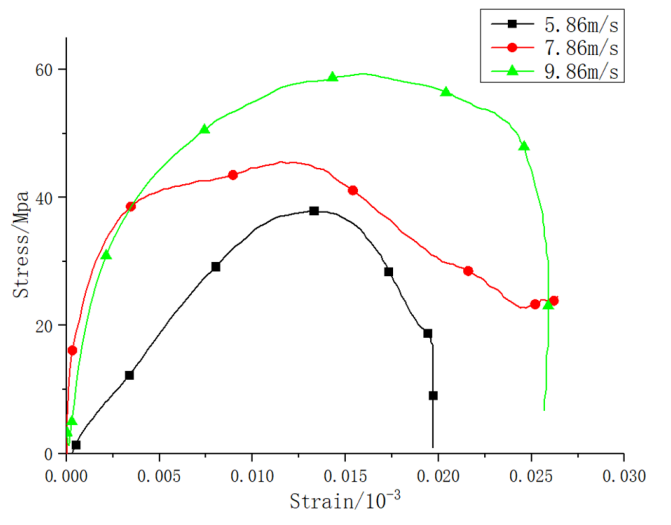

(c) $400{ }^{\circ} \mathrm{C}$

Figure 19. The stress-strain curve of basalt fiber-reinforced concrete under three loading rates. 
With the increase of the loading rate, the impact energy increases rapidly, the internal energy of concrete increases rapidly, and it does not have time to release; therefore, the dynamic compressive strength of concrete is increased.

\subsubsection{Effect of High Temperature on Dynamic Compressive Strength}

The dynamic compressive temperature-strength curves of ordinary concrete and basalt fiber-reinforced concrete at various heating temperatures are shown as follows (Figure 20):

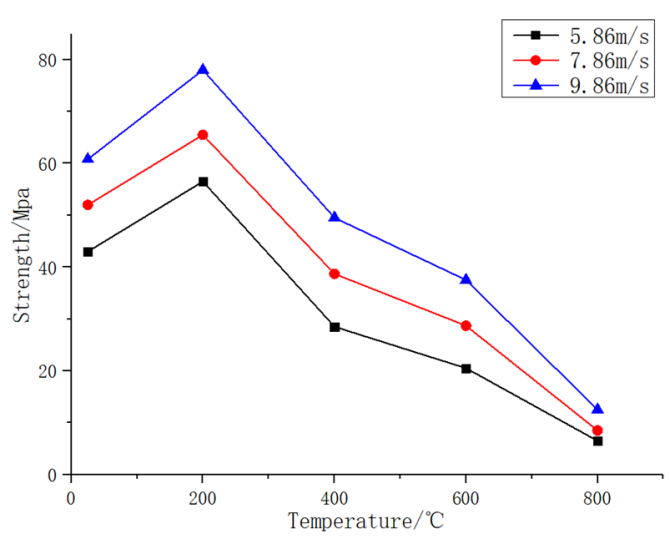

(a) Ordinary concrete

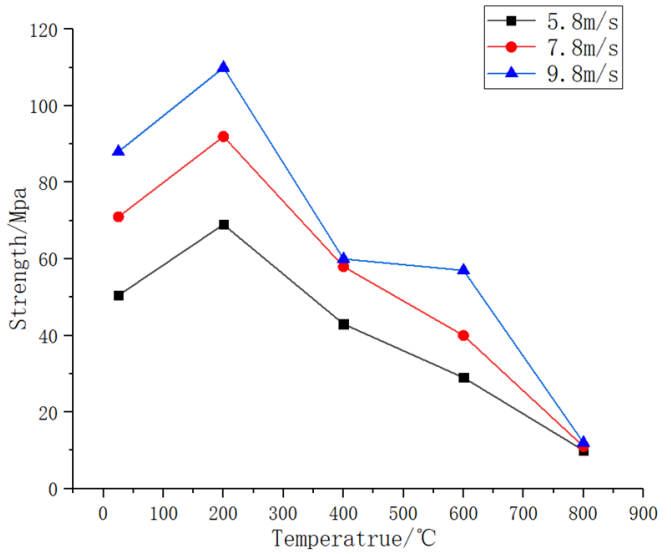

(b) Basalt fiber-reinforced concrete

Figure 20. The dynamic compressive temperature-strength curves of two concrete.

It can be seen from the Figure 20 that the dynamic compressive strength of ordinary concrete and basalt fiber-reinforced concrete increases first and reaches a peak when the temperature increases to $200{ }^{\circ} \mathrm{C}$. After, with the further increase of the temperature, the dynamic compressive strength of concrete declines rapidly. When the temperature reaches $400{ }^{\circ} \mathrm{C}$, the compressive strength of concrete is less than at $25{ }^{\circ} \mathrm{C}$. When the temperature reaches $800{ }^{\circ} \mathrm{C}$, the ordinary concrete and basalt fiber-reinforced concrete loses the bearing capacity.

When the loading rate is $5.8 \mathrm{~m} / \mathrm{s}$, compared with room temperature $\left(25^{\circ} \mathrm{C}\right)$, the dynamic compressive strength of ordinary concrete improves by $31.3 \%, 33.7 \%, 53.4 \%$, and $84.8 \%$ at $200,400,600$, and $800{ }^{\circ} \mathrm{C}$, respectively, while the dynamic compressive strength of basalt fiber-reinforced concrete improves by $43.3 \%, 11.6 \%, 50.2 \%$, and $75.7 \%$ at $200,400,600$, and $800{ }^{\circ} \mathrm{C}$, respectively. When the loading rate is $7.8 \mathrm{~m} / \mathrm{s}$, compared with room temperature $\left(25^{\circ} \mathrm{C}\right)$, the dynamic compressive strength of ordinary concrete improves by $25.5 \%, 25.5 \%, 44.8 \%$, and $83.6 \%$ at $200,400,600$, and $800{ }^{\circ} \mathrm{C}$, respectively, while the dynamic compressive strength of basalt fiber-reinforced concrete improves by $13.6 \%$, $25 . .8 \%, 46.6 \%$, and $80.8 \%$ at $200,400,600$, and $800{ }^{\circ} \mathrm{C}$, respectively. When the loading rate is $9.8 \mathrm{~m} / \mathrm{s}$, compared with room temperature $\left(25^{\circ} \mathrm{C}\right)$, the dynamic compressive strength of ordinary concrete improves by $28.3 \%, 18.5 \%, 38.3 \%$, and $79.4 \%$ at $200,400,600$, and $800{ }^{\circ} \mathrm{C}$, respectively, while the dynamic compressive strength of basalt fiber-reinforced concrete improves by $25.7 \%, 19.4 \%, 48 \%$, and $76 \%$ at $200,400,600$, and $800{ }^{\circ} \mathrm{C}$, respectively.

When the temperature is less than $200{ }^{\circ} \mathrm{C}$, a thermal strengthening effect is observed. At this stage, free water escapes constantly, and due to thermal expansion and cold contraction, the tiny cracks of concrete are reduced with the expansion of the aggregate and vapor increases the internal pressure. With the increase of the dynamic loading, the internal cracks of concrete are pressed and the stress concentration of the concrete is decreased; therefore, the strength of the concrete is improved. When the temperature exceeds $200{ }^{\circ} \mathrm{C}$, the bound water inside the concrete begins to precipitate, and the interaction of the cement in the concrete is enhanced. Due to the concrete thermal expansion, the coefficients of the coarse aggregate and additives are different, and a lot of thermal damage to the joint of the 
concrete is caused. Under the influence of these two factors, the strength of the concrete decreased and is less than at room temperature. When the temperature reaches $600^{\circ} \mathrm{C}$, the hydrate, like $\mathrm{NaOH}$, of the concrete begin dehydration and produce $\mathrm{NaO}$, the volume is expanded, and the fractures in the concrete are developed further. When the temperature reaches $800{ }^{\circ} \mathrm{C}$, the strength of the aggregate in concrete is lost and the concrete becomes completely loose.

\subsubsection{Effect of the Two Cooling Methods on the Failure Pattern}

Under the impact velocity of $5.8 \mathrm{~m} / \mathrm{s}$, the failure patterns of the two concretes using the air-cooling method and water-cooling methods were compared.

The dynamic failure modes are closely related to the mechanical behavior of a material. Figures 21-24 show the typical failure patterns of concrete specimens at different treatment temperatures. There are four failure patterns: edge failure, core retention failure, crushing failure, and smashing failure. It is observed that with the increase of the temperature, the fragmentation of the concrete specimens worsens and the fragment sizes become smaller.

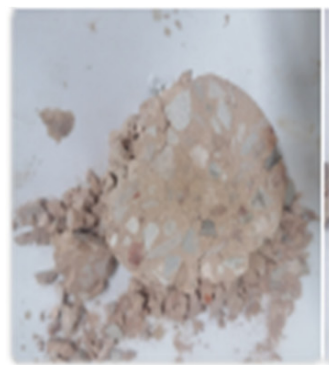

(a) $25^{\circ} \mathrm{C}$

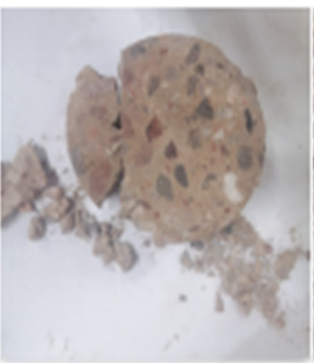

(b) $200{ }^{\circ} \mathrm{C}$

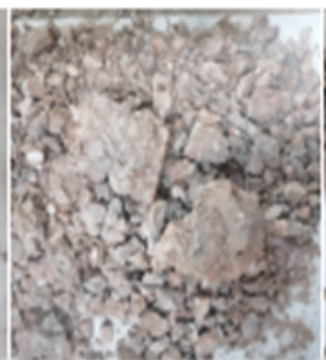

(c) $400{ }^{\circ} \mathrm{C}$

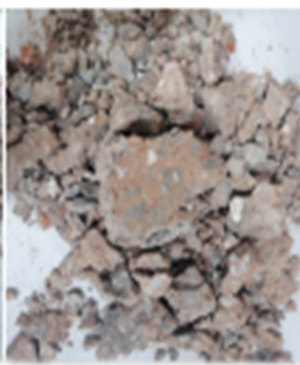

(d) $600{ }^{\circ} \mathrm{C}$

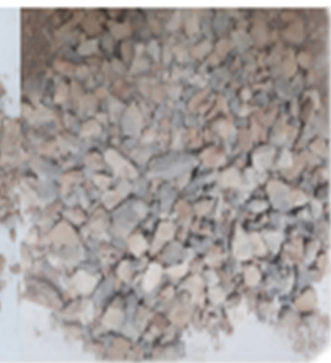

(e) $800{ }^{\circ} \mathrm{C}$

Figure 21. The failure patterns of ordinary concrete using the air-cooling method.

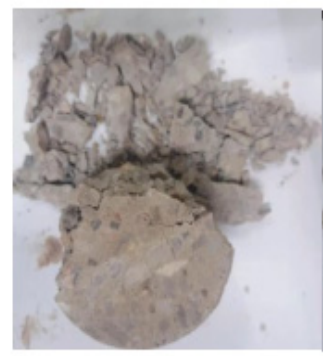

(a) $25^{\circ} \mathrm{C}$

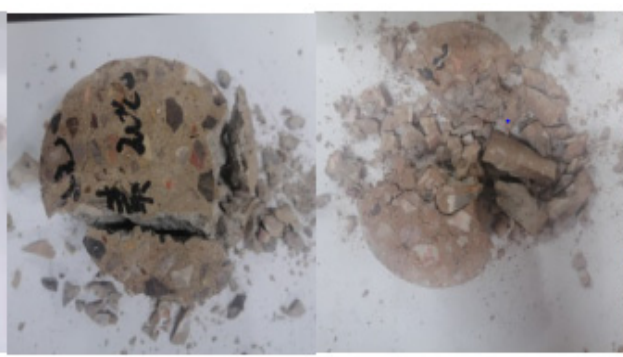

(c) $400{ }^{\circ} \mathrm{C}$

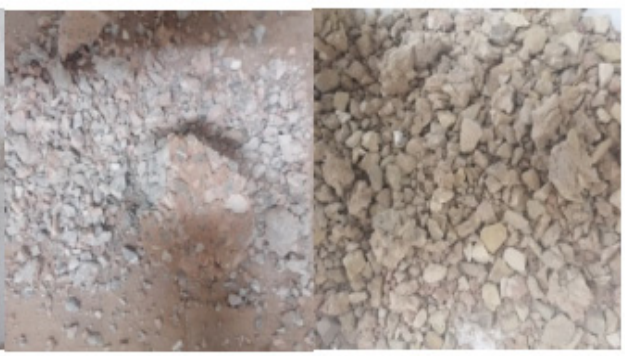

(d) $600{ }^{\circ} \mathrm{C}$

(e) $800{ }^{\circ} \mathrm{C}$

Figure 22. The failure patterns of ordinary concrete using the water-cooling method.

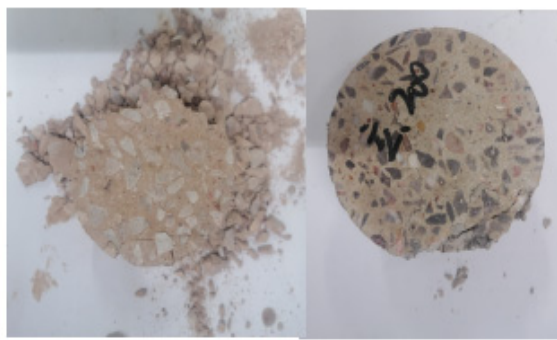

(a) $25^{\circ} \mathrm{C}$

(b) $200{ }^{\circ} \mathrm{C}$

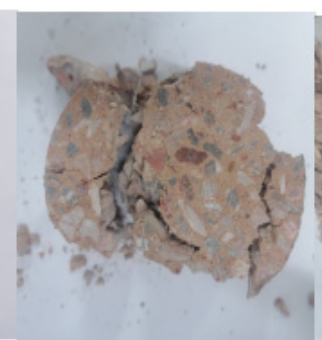

(c) $400^{\circ} \mathrm{C}$

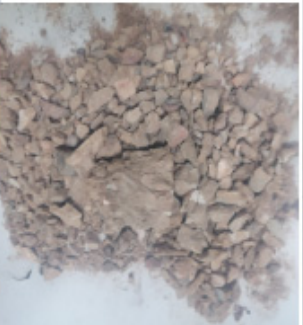

(d) $600{ }^{\circ} \mathrm{C}$

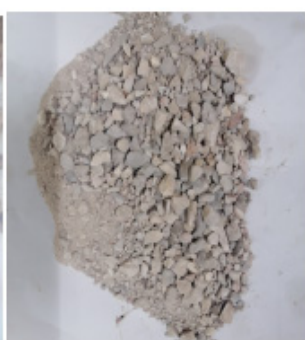

(e) $800{ }^{\circ} \mathrm{C}$

Figure 23. The failure patterns of basalt concrete using the air-cooling method. 


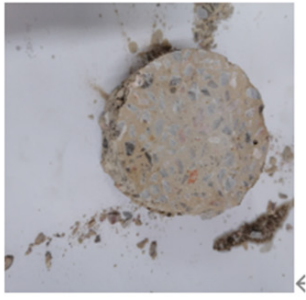

(a) $25^{\circ} \mathrm{C}$

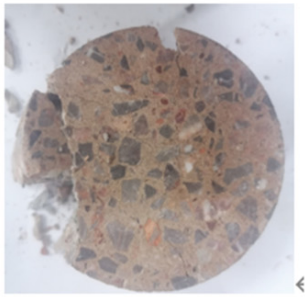

(b) $200{ }^{\circ} \mathrm{C}$

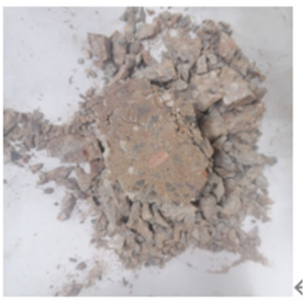

(c) $400{ }^{\circ} \mathrm{C}$

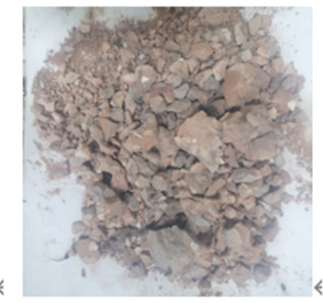

(d) $600{ }^{\circ} \mathrm{C}$

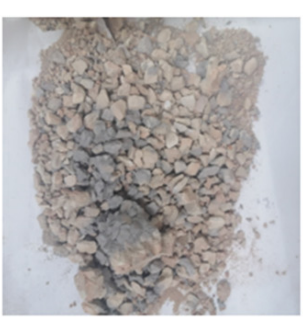

(e) $800{ }^{\circ} \mathrm{C}$

Figure 24. The failure patterns of basalt concrete using the water-cooling method.

At room temperature $\left(25^{\circ} \mathrm{C}\right)$, the failure pattern of ordinary concrete is crushing failure while the failure pattern of basalt fiber-reinforced concrete is core retention failure. When the temperature reaches $200{ }^{\circ} \mathrm{C}$, both ordinary concrete and basalt concrete show edge failure and core retention failure. With the further increase of the temperature, crushing failure and smashing failure are generated in both ordinary concrete and basalt concrete. When the temperature reaches $800{ }^{\circ} \mathrm{C}$, the coarse aggregate of concrete forms crystals and the internal structure is damaged. After subjecting it to impact loading, the concrete specimens are a powder state. However, compared with the air-cooled specimens, the water-cooled specimens are smashed into irregular and smaller pieces at the same temperature.

\subsubsection{The Dynamic Constitutive Model of Basalt Fiber-Reinforced Concrete}

In this section, the dynamic compressive strength-temperature constitutive model of basalt fiber-reinforced concrete exposed to various high temperatures and different cooling methods under the dynamic load rate of $5.8 \mathrm{~m} / \mathrm{s}$ is established as Equation (4):

$$
f=t_{1}+t_{2}+t_{3} T^{2}+t_{3} T^{3}
$$

$\mathrm{f}-$ Compressive strength (Mpa).

$\mathrm{T}$-Temperature $\left({ }^{\circ} \mathrm{C}\right)$.

Based on the Equation (4), the constitutive model of basalt fiber-reinforced concrete after air cooling was shown in Figure 25 and its fitting parameters were recorded in Table 18.

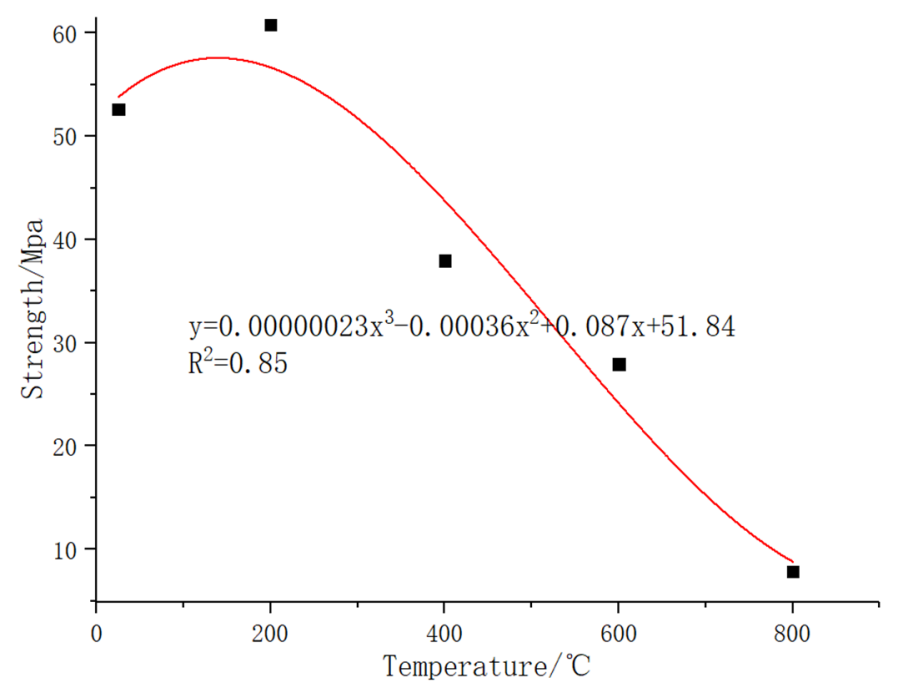

Figure 25. The constitutive model of basalt fiber-reinforced concrete after air cooling. 
Table 18. The fitting parameters of dynamic compressive strength of basalt fiber-reinforced concrete after air cooling.

\begin{tabular}{ccccc}
\hline Parameters & $\mathbf{t}_{\mathbf{1}}$ & $\mathbf{t}_{\mathbf{2}}$ & $\mathbf{t}_{\mathbf{3}}$ & $\mathbf{t}_{\mathbf{4}}$ \\
\hline basalt fiber-reinforced concrete & 51.84 & 0.087 & $3.6 \times 10^{-4}$ & $2.3 \times 10^{-7}$ \\
\hline
\end{tabular}

According to Equation (4) and the above experimental results, the constitutive model of basalt fiber-reinforced concrete after air cooling under a load rate of $5.8 \mathrm{~m} / \mathrm{s}$ is as follows:

$$
\mathrm{f}=51.84+0.087 \mathrm{~T}+0.00036 \mathrm{~T}^{2}+0.00000023 \mathrm{~T}^{3}
$$

$\mathrm{R}^{2}=0.85$.

Based on the Equation (4), the constitutive model of basalt fiber-reinforced concrete after water cooling was shown in Figure 26 and its fitting parameters were recorded in Table 19.

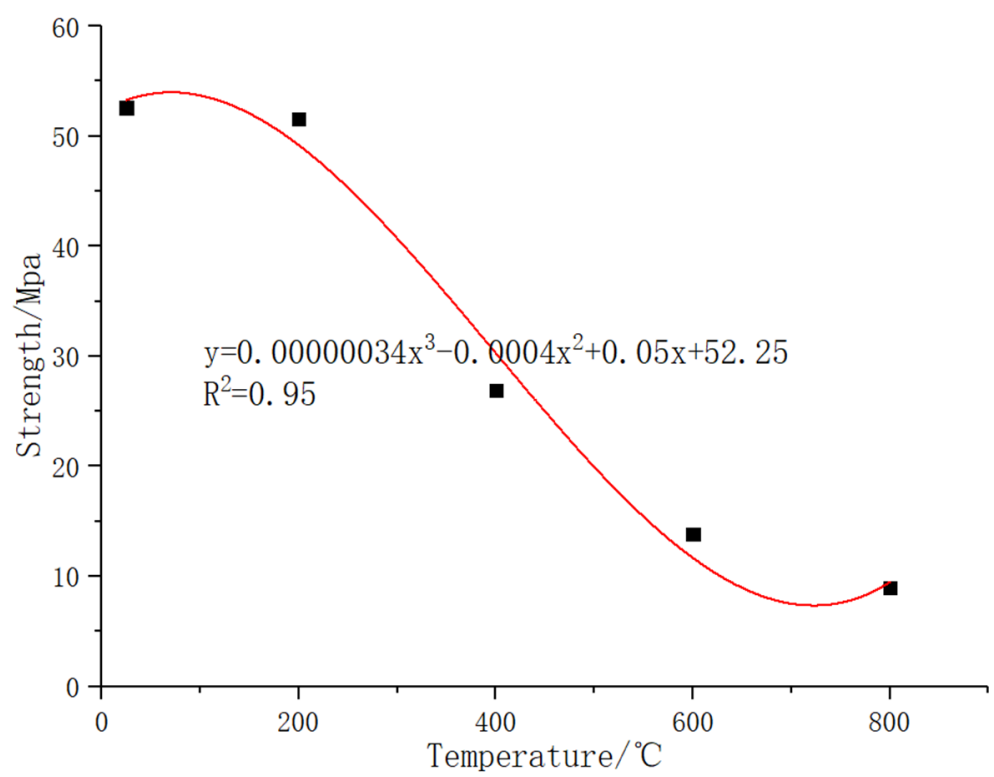

Figure 26. The constitutive model of basalt fiber-reinforced concrete after water cooling.

Table 19. The fitting parameters of dynamic compressive strength of basalt fiber-reinforced concrete after water cooling.

\begin{tabular}{ccccc}
\hline Parameters & $\mathbf{t}_{\mathbf{1}}$ & $\mathbf{t}_{\mathbf{2}}$ & $\mathbf{t}_{\mathbf{3}}$ & $\mathbf{t}_{\mathbf{4}}$ \\
\hline basalt fiber-reinforced concrete & 52.25 & 0.05 & $-4 \times 10^{-4}$ & $3.4 \times 10^{-7}$ \\
\hline
\end{tabular}

The constitutive model of basalt fiber-reinforced concrete in water cooling under the load rate of $5.8 \mathrm{~m} / \mathrm{s}$ is as follows:

$$
f=52.25+0.05 T-0.0004 T^{2}+0.00000034 T^{3}
$$

$\mathrm{R}^{2}=0.95$.

\subsubsection{Comparison between Ordinary Concrete and Basalt Fiber-Reinforced Concrete}

At the same temperatures $\left(25,200\right.$, and $\left.400^{\circ} \mathrm{C}\right)$, the comparison figures of the stressstrain curves of ordinary concrete and basalt fiber-reinforced concrete are shown as follows:

Figure 27 shows the dynamic compressive stress-strain curves of the ordinary concrete specimens and basalt fiber-reinforced concrete specimens subjected to different elevated temperatures under dynamic loading. The experimental results show that the dynamic 
compressive strength decreases and the peak strain increases with the increase of the temperature for the same strain rate state. At the same temperature, the dynamic compressive strength increases with the increase of the loading rates.

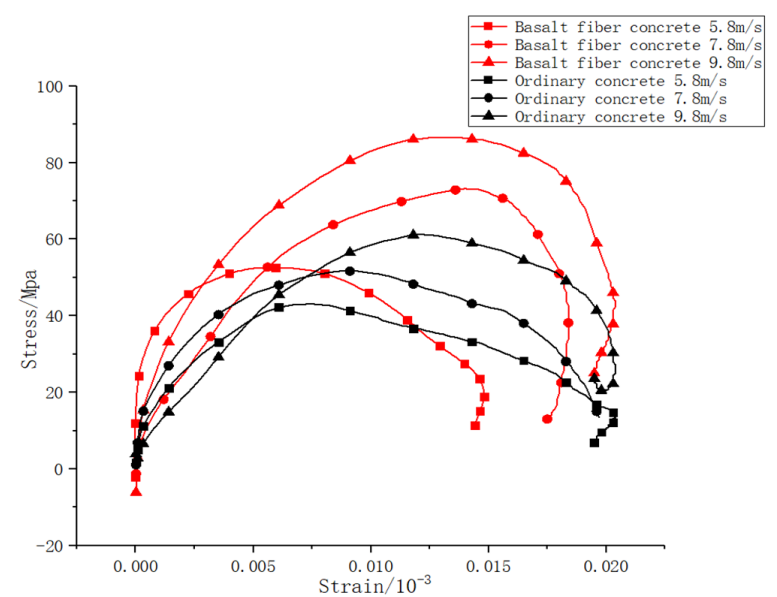

(a) $25^{\circ} \mathrm{C}$

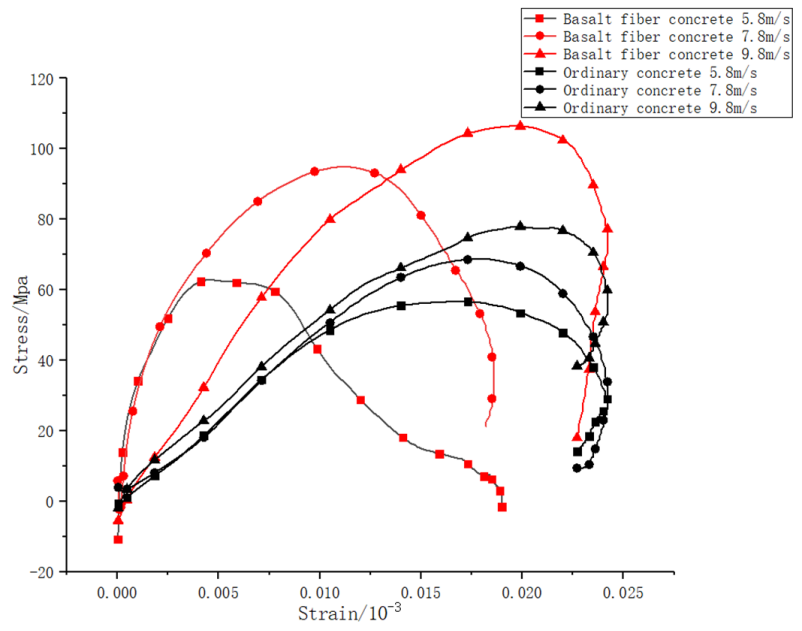

(b) $200{ }^{\circ} \mathrm{C}$

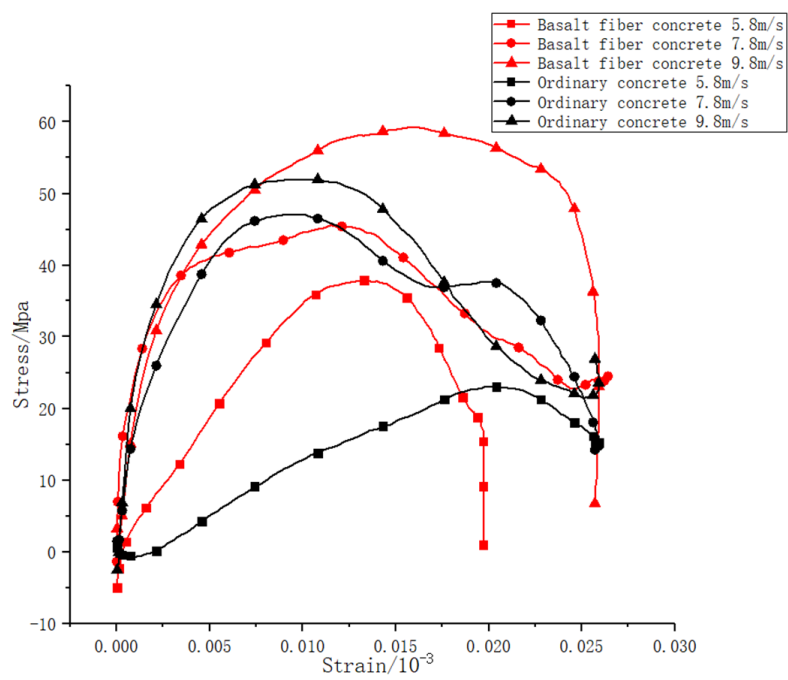

(c) $400{ }^{\circ} \mathrm{C}$

Figure 27. The comparison figures of the stress-strain curves of the two concretes. 
In addition, the dynamic compressive strength of basalt fiber-reinforced concrete is better than ordinary concrete at every temperature on the whole; that is to say, the addition of basalt fiber in concrete can effectively increase the toughness of concrete and improve the dynamic compressive strength of concrete.

The comparison figures of the temperature-strength curves of ordinary concrete and basalt fiber-reinforced concrete are shown as follows:

Figure 28 shows that the strength of the two concretes increases with the increase of the temperature and reaches peak strength when the temperature reaches $200{ }^{\circ} \mathrm{C}$. After, the strength both of basalt fiber-reinforced concrete and ordinary concrete begins to decrease continuously. This is attributed to the rehydration of lime accompanied by a volume increase, which converts the $\mathrm{CaCO}_{3}$ into $\mathrm{CaO}$ and causes cracking and crumbling of concrete materials at high temperatures.

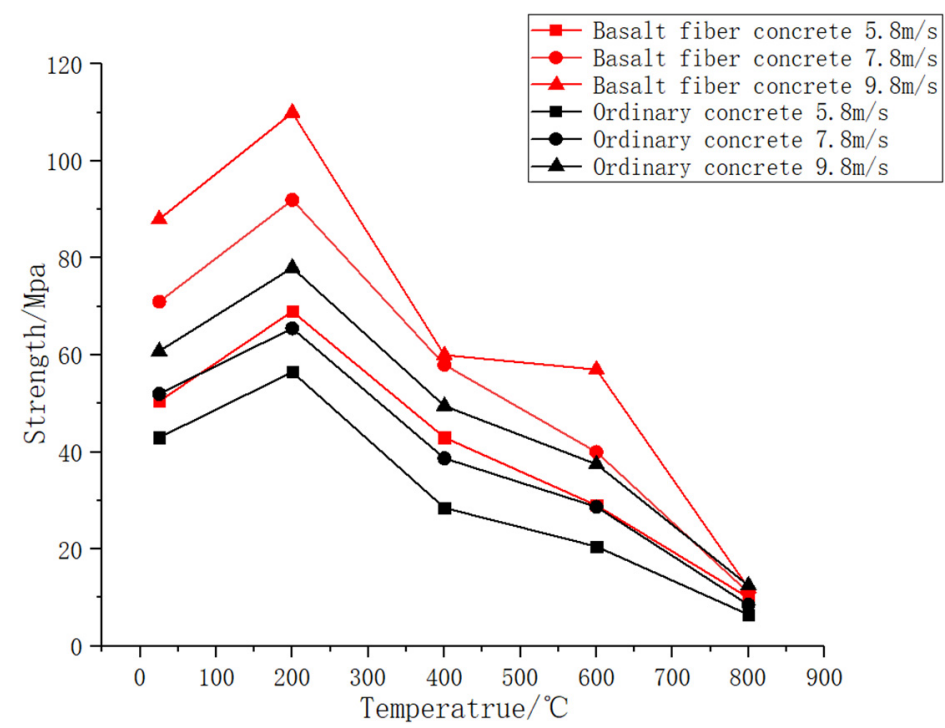

Figure 28. The comparison figures of the temperature-strength curves of the two concretes.

However, under the same temperature and loading rate, the strength of basalt fiberreinforced concrete is bigger than ordinary concrete. This also confirms that the addition of basalt fiber to concrete can significantly increase the dynamic compressive strength of concrete.

\section{Conclusions}

In this experiment, the YAW-2000C constant stress pressure experimental machine was used to carry out the static compressive test, and the split-Hopkinson pressure bar was used to carry out the dynamic impact test, and the static compressive strength and dynamic compressive strength of ordinary concrete and basalt fiber-reinforced concrete under various of heating temperatures and cooling methods (air-cooled method and water-cooled method) were investigated. Through the experimental data, the conclusions are as follows:

(1) With the increase of the temperature, the physical parameters of the two concretes changed, such as mass, wave velocity, and color. The mass loss of two concretes increases with the increase of temperature. The wave velocity of two concretes is descending with the increase of the temperature, but the mass loss rate of basalt fiber-reinforced concrete is less than ordinary concrete. Thus, high temperatures produce a detrimental effect on the mechanical property of concrete and the mechanical property of basalt fiber-reinforced concrete is better than ordinary concrete. Moreover, with the temperature increasing, the color of concrete gradually changes from dark blue to red. When the temperature reaches $800{ }^{\circ} \mathrm{C}$, the concrete gradually turns white. However, compared with ordinary concrete, the color change with the temperature of basalt fiber-reinforced concrete shows hysteresis. 
(2) The static compressive strength of both ordinary concrete and basalt fiber-reinforced concrete increases when the temperature is $25 \sim 200{ }^{\circ} \mathrm{C}$, and the strength reaches a peak when the temperature increases to $200^{\circ} \mathrm{C}$. After, the static compressive strength begins to decrease with the increase of the temperature. When the temperature increases to $400^{\circ} \mathrm{C}$, the static compressive strength of the two concretes is lower than at room temperature under the same conditions, and when the temperature rises to $800^{\circ} \mathrm{C}$, the concretes lose their bearing capacity. However, at the same temperature, the static compressive strength of basalt fiber-reinforced concrete is bigger than ordinary concrete. In addition, the static compressive strength of the concretes after cooling in air is greater than that after cooling in water, and the fracture for the water-cooled specimen is bigger than for the air-cooled specimen at the same heating temperature.

(3) The dynamic compressive strength of the concretes is affected by the loading rate and temperature. The dynamic compressive strength of concretes is bigger than the static compressive strength of concrete at the same conditions and increases with the increase of the loading rate. At the same loading rate, the dynamic compressive strength of basalt fiber-reinforced concrete is bigger than ordinary concrete. Within $t$ $25 \sim 200{ }^{\circ} \mathrm{C}$, the strength increases when the temperature increases and reaches a peak when the temperature increases to $200{ }^{\circ} \mathrm{C}$. After, the strength begins to decline with the further increase of the temperature. At the same loading rate and heating temperature, the dynamic compressive strength of basalt fiber-reinforced concrete is bigger than ordinary concrete. In addition, the crushing form of concrete specimens cooled by air is better than those cooled by water; however, in the same conditions, the crushing form of basalt fiber-reinforced concrete is better than ordinary concrete.

(4) The addition of basalt fiber to concrete can significantly improve the mechanical property of concrete. The use of basalt fiber-reinforced concrete can largely enhance the fire resistance of the structure and improve the security after being subjected to conflagration or other high-temperature conditions.

Author Contributions: Conceptualization, L.L. and H.A.; methodology, L.L. and H.A.; formal analysis, X.M., Y.S.; investigation, X.M., Y.S.; writing-original draft preparation, Y.S., H.A.; funding acquisition, L.L. All authors have read and agreed to the published version of the manuscript.

Funding: This work was partly supported by the National Science Foundation of China (Grant no. 11862010), Science and Research Fund from the Educational Department of Yunnan Province (Grant nos. 2020J0051 and KKJJ202067001); Research Start-Up Fund for Talent of Kunming University of Science and Technology (Grant no. KKSY201867017), Program for Innovative Research Team (in Science and Technology) in University of Yunnan Province, Funding from the Research Center for Analysis and Measurement KUST (Analytic and Testing Research Center of Yunnan, Grant number 2020T20180040), and Yunnan Key Laboratory of Sino-German Blue Mining and Utilization of Special Underground Space, which are greatly appreciated.

Data Availability Statement: The data used to support the findings of this study are included within the article.

Conflicts of Interest: The authors declare no conflict of interest.

\section{References}

1. Delatte, N.J. Lessons from Roman Cement and Concrete. J. Prof. Issues Eng. Educ. Pract. 2001, 127, 109-115. [CrossRef]

2. Lie, T.T.; Kodur, V.K.R. Thermal Properties of Fiber-Reinforced Concrete at Elevated Temperature; National Rechearch Council Canada: Ottawa, ON, Canada, 1995.

3. Nagy, B.; Nehme, S.G.; Szagri, D. Thermal Properties and Modeling of Fiber Reinforced Concretes. Energy Procedia 2015, 78, 2742-2747. [CrossRef]

4. Liang, X.W.; Wu, C.Q. Investigation on thermal conductivity of steel fiber reinforced concrete using mesoscale modeling. Int. J. Thermophys. 2018, 39, 1-19. [CrossRef]

5. Zheng, W.Z.; Li, H.Y.; Wang, Y. Compressive stress-strain relationship of steel fiber-reinforced reactive powder concrete after exposure to elevated temperatures. Constr. Build. Mater. 2012, 35, 931-940. [CrossRef]

6. Aslani, F.; Samali, B. Constitutive relationships for steel fiber reinforced concrete at elevated temperatures. Fire Technol. 2014, 50, 1249-1268. [CrossRef] 
7. Zheng, D.; Song, W.; Fu, J.; Xue, G.; Li, J.; Cao, S. Research on mechanical characteristics, fractal dimension and internal structure of fiber reinforced concrete under uniaxial compression. Constr. Build. Mater. 2020, 258, 120351. [CrossRef]

8. Hung, C.-C.; Chen, Y.-T.; Yen, C.-H. Workability, fiber distribution, and mechanical properties of UHPC with hooked end steel macro-fibers. Constr. Build. Mater. 2020, 260, 119944. [CrossRef]

9. Ali, B.; Qureshi, L.A.; Khan, S.U. Flexural behavior of glass fiber-reinforced recycled aggregate concrete and its impact on the cost and carbon footprint of concrete pavement. Constr. Build. Mater. 2020, 262, 120820. [CrossRef]

10. Guo, Y.; Zhang, J.; Chen, G.; Xie, Z. Fracture behaviors of a new steel fiber reinforced recycled aggregate concrete with crumb rubber. Constr. Build. Mater. 2014, 53, 32-39. [CrossRef]

11. Kodur, V.K.R.; Cheng, F.-P.; Wang, T.-C.; Sultan, M.A. Effect of Strength and Fiber Reinforcement on Fire Resistance of HighStrength Concrete Columns. J. Struct. Eng. 2003, 129, 253-259. [CrossRef]

12. Zhang, P.; Kang, L.; Wang, J.; Guo, J.; Hu, S.; Ling, Y. Mechanical Properties and Explosive Spalling Behavior of Steel-FiberReinforced Concrete Exposed to High Temperature-A Review. Appl. Sci. 2020, 10, 2324. [CrossRef]

13. Ding, Y.; Zhang, F.; Pacheco-Torgal, F.; Zhang, Y. Shear behaviour of steel fibre reinforced self-consolidating concrete beams based on the modified compression field theory. Compos. Struct. 2012, 94, 2440-2449. [CrossRef]

14. Eik, M.; Puttonen, J.; Herrmann, H. An orthotropic material model for steel fibre reinforced concrete based on the orientation distribution of fibres. Compos. Struct. 2015, 121, 324-336. [CrossRef]

15. Abdallah, S.; Fan, M.; Zhou, X.; Le Geyt, S. Anchorage Effects of Various Steel Fibre Architectures for Concrete Reinforcement. Int. J. Concr. Struct. Mater. 2016, 10, 325-335. [CrossRef]

16. Kearsley, E.; Wainwright, P. The effect of porosity on the strength of foamed concrete. Cem. Concr. Res. 2002, 32, 233-239. [CrossRef]

17. Ismail, M.; Ismail, M.E.; Muhammad, B. Influence of elevated temperatures on physical and compressive strength properties of concrete containing palm oil fuel ash. Constr. Build. Mater. 2010, 25, 2358-2364. [CrossRef]

18. Ren, W.; Xu, J.; Su, H. Dynamic compressive behavior of basalt fiber reinforced concrete after exposure to elevated temperatures. Fire Mater. 2016, 40, 738-755. [CrossRef]

19. Novák, J.; Kohoutková, A. Fire response of Hybrid Fiber Reinforced Concrete to High Temperature. Procedia Eng. 2017, 172, 784-790. [CrossRef]

20. Khosravani, M.R.; Weinberg, K. A review on split Hopkinson bar experiments on the dynamic characterisation of concrete. Constr. Build. Mater. 2018, 190, 1264-1283. [CrossRef]

21. Yang, D.; Wang, X.; Wang, Y.; An, H.; Lei, Z. Experiment and Analysis of Wedge Cutting Angle on Cutting Effect. Adv. Civ. Eng. 2020, 2020, 1-16. [CrossRef]

22. Liu, L.; An, H.M. Experimental study of compressive failure of concrete under static and dynamic loads. Arch. Civ. Eng. 2020, 66, 427-441.

23. An, H.; Zeng, T.; Zhang, Z.; Liu, L. Experimental Study of the Rock Mechanism under Coupled High Temperatures and Dynamic Loads. Adv. Civ. Eng. 2020, 2020, 1-19. [CrossRef]

24. An, H.; Hou, S.; Liu, L. Experimental and Numerical Study of the Concrete Stress and Fracture Propagation Processes by Blast. Eng. Lett. 2019, 27, 669-675.

25. Chen, B.; Liu, J. Residual strength of hybrid-fiber-reinforced high-strength concrete after exposure to high temperatures. Cem. Concr. Res. 2004, 34, 1065-1069. [CrossRef]

26. Zongping, C.H.E.N.; Houran, L.I.A.N.G. Study on compressive strength of recycled pebble concrete after high temperature and water cooling by rebound method. Concrete 2020, 07, 130-134. [CrossRef]

27. Qiang, L.I. A damange model for concrete subject to high temperatrue bassed on tarallel hypothesis. Low Temp. Archit. Technol. 2017, 39, 19-22.

28. Bin, J.I.A.; Fan, Y.A.N.G.; Junlin, T.A.O.; Huachan, Y.A.O. High-temperature mechanical behaviors constitutive model of concrete. Concrete 2014, 02, 25-28. [CrossRef] 